\title{
A Strategic Approach to Value Chain Upgrading-Adopting Innovations and Their Impacts on Farm Households in Tanzania
}

\author{
Jesse Steffens *, Kathleen Brüssow ${ }^{(10}$ and Ulrike Grote \\ Institute for Environmental Economics and World Trade, Leibniz University Hannover, Königsworther Platz 1, \\ 30167 Hannover, Germany; bruessow@iuw.uni-hannover.de (K.B.); grote@iuw.uni-hannover.de (U.G.) \\ * Correspondence: jessesteffens@web.de
}

Received: 26 March 2020; Accepted: 22 May 2020; Published: 2 June 2020

\begin{abstract}
The level of agricultural productivity in Sub-Saharan Africa remains far below the global average. This is partly due to the scarce use of production- and process-enhancing technologies. This study aims to explore the driving forces and effects of adopting innovative agricultural technologies in food value chains (FVC). These enhancing FVC technologies are referred to as upgrading strategies (UPS) and are designed to improve specific aspects of crop production, postharvest processing, market interaction, and consumption. Based on cross-sectional data collected from 820 Tanzanian farm households, this study utilized the adaptive lasso to analyse the determinants of UPS. To measure the impact of their adoption on well-being, this study applied the propensity score matching approach (PSM). Results from the adaptive lasso suggested that access to credit, experience of environmental shocks and social capital were the main drivers of UPS adoption. In contrast, the engagement in off-farm wage employment impeded adoption. The results from the PSM suggested that UPS adoption has a positive and significant impact on well-being among sampled households, especially with respect to their total value of durable goods and commercialization. The paper suggests that the promotion of social capital and access to financial capital is pivotal in enhancing the adoption of innovative UPS in the farming sector.
\end{abstract}

Keywords: value chain analysis; innovations; adaptive lasso; propensity score matching; Tanzania

\section{Introduction}

Over the last decades, many technological improvements were promoted to increase productivity in the agricultural sector in Sub-Saharan Africa (SSA). Nevertheless, the average agricultural growth rate is still well below the targeted 6\% as declared by the Comprehensive Africa Agriculture Development Program [1]. This is also the case for Tanzania. Here, about $70 \%$ of the economic value is derived from agriculture and most of the population lives in rural areas and their main source of livelihood is linked to food value chains (FVCs) [2]. FVCs link participants and activities that bring an agricultural product from production at the farm gate to final consumption, with value being added at each stage [3]. Nonetheless, huge portions of what rural farmers produce is consumed within the households, which point at short subsistence-oriented FVCs [4]. Due to the absence of agricultural technologies and sustainable storage facilities, estimated output losses amount to $30 \%$ and more throughout FVCs $[5,6]$. Adopting innovations as improvements in agriculture are necessary, particularly in terms of production at farm level as well as yields and cultivation intensity, in order to promote FVCs. Nonetheless, farmers face multiple constraints such as reliance on rainfall, low soil fertility and weak market systems. Most of these factors diminish yields and efficient trading, hindering farmers from sustaining their basic needs and increasing their income $[7,8]$. To encounter these challenges, many development 
interventions and strategies are contentious or have already been implemented [8-10]. Therefore, it is pivotal that innovative upgrading strategies (UPS) alter the diverse obstacles that rural farmers are facing to stimulate FVCs most effectively. For the purpose of this study, UPS are defined as sets of good practices and agricultural technologies used for securing food along the value chain at local and regional levels [11]. They may, by their nature, target improving efficiency, agricultural output and livelihoods by introducing machinery at their location [12]. Another target of UPS is to smoothen temporal food availability, enhance stored grain quality and increase poor farmers' incomes through increased opportunities for market interaction [13]. Succinctly, UPS should stimulate value addition and simultaneously address food security, poverty reduction and income stability through the effective sustainable management of resources [11,14]. Additionally, UPS should fit into existing local and regional FVCs, must consider the local relational household context and be jointly developed with local stakeholders [15]. This study focuses on three specific UPS, namely, a maize-sheller, a millet-thresher and storage superbags. These three devices enhance either production and/or processing stages within the FVCs.

The driving forces of rural farmers decisions about whether to adopt a certain innovation or strategy are very closely linked to the "innovation-diffusion theory" by Rogers [16]. According to the theory, a few farmers are initially willing to try an innovation. As these few early adopters "spread the word" more and more people become aware of the innovation and over time, the innovation spreads. Finally, the more risk averse and poorer farmers adopt the innovation. The assumption that the adoption of innovations is influenced by social interaction and the perceived need for change is reinforced by empirical findings [16,17]. Thus, most of the constraints related to adoption are lack of credit, lack of access to information and markets, unfavourable geographical areas and poor infrastructure, risk aversion and social capital of farmers [16,18-24].

Numerous empirical studies also examined the relationship between demographic and socioeconomic factors and adoption behaviour $[18,24]$. Younger farmers have been found to more likely adopt a new agricultural technology than older ones. However, older farmers possess more physical capital and are more experienced in adopting UPS, hence, the impact of age on technology adoption is ambiguous [9]. Better educated households are more likely to adopt new technologies and are more likely to benefit from their social network [23]. Labour input is used as a proxy and is associated with the nucleus size of a household [25]. The larger the household size, the more labour is available for agricultural production and the higher the likelihood of adoption. In addition, the farm size increases the adoption of innovations [26,27].

Access to credit helps rural farmers access inputs and labour. A higher asset score is associated with a higher probability of adopting technologies [28]. The existence of off-farm income acts as a strategy to overcome the capital and credit constraints related to intense capital-related technologies faced by rural households [29]. According to Ellis and Freeman [30], off-farm income may substitute for borrowed capital in rural households where capital markets or credit facilities are dysfunctional, hence, increasing the likelihood of adoption. Other studies report that it may reduce the labour input to on-farm activities, therefore reducing the likelihood of adoption [31].

Social capital in the form of social groups in a cooperative enhances trust, as a result improving idea exchange and spreading the exchange of information. Farmers who can learn about the benefits of a particular innovation share this information within the group and spread it within their social network. Therefore, collective processing and the production of crop cultivation enhance the probability of adopting an UPS [32,33]. According to Barrett [22], farmers engage more in effective FVCs if they are provided with postharvest handling activities such as storage. This implies that the likelihood of adopting an enhancing market-oriented storing technology increases if households decide to store crops for selling. The distance from homestead to markets is seen as a path-leading driver for technology adoption. The closer farm land is to main roads or market centres, the more farmers benefit from transportation facilities, hence increasing the likelihood of adoption [34]. 
Adoption decisions are also influenced by the household's perception of land security [35]. Results of a study conducted in Ethiopia by Teklewold and Köhlin [36] show that a high degree of risk aversion decreases the probability of adopting soil conservation practices. Cavatassi et al. [37] argue that unexpected climatic disasters such as droughts or floods may drive farmers to avoid adopting any UPS. Farmers who have been most vulnerable to extreme weather events are less likely to use process-enhancing fertilizer since the plot will be affected on an interim basis. In this context, a climate-related shock may additionally lead to an income loss. Following the framework of Grothmann and Patt [38], farmers that experience climate-related shocks in a higher frequency or severity have an increased likelihood of adopting several strategies. This implies that the farmers either respond precautiously with long-term strategies that might involve some monetary investment such as an UPS or they respond reactively.

There are only a few impact studies analysing performance enhancing machinery and optimized market storage in SSA regions and in Tanzania in particular. Those that do are predominantly ex ante impact studies [10]. The ex-ante impact assessment studies conducted in Tanzania showed a positive impact of UPS, resulting in higher income and market participation measured by the household commercialization index (HCI) [10]. A study conducted in Nigeria revealed that farmers who adopted UPS machinery devices for improved processing activities realized beneficial outcomes [12]. These beneficial outcomes ranged from increased efficiency in the process of shelling, lowering labour input of shelling and reducing wastage of grains produced, to creation of employment for the youth. UPS in the form of improved bags for market-oriented storage has proven successful in Tanzania, Mozambique, Ghana and Malawi. The study showed that higher prices, at around 50\%, were obtained for grains and maize $[13,39]$.

Studies conducted in Tanzania and Ethiopia showed a positive impact of improved processing technologies on consumption expenditures for durable goods [23,40]. Thus, the increase in consumption expenditure on durable goods serves as a proxy for their well-being and indicates that if the value of durable goods increases, it shows a rise in overall well-being of rural farmers. Shiferaw et al. [41] investigated the role of process-enhancing pigeon pea varieties by using the augmented double-hurdle model. Their results suggested that household income improved by up to $80 \%$ for those who used the agricultural technology. Furthermore, their disease-induced yield losses decreased by about $50 \%$ for local varieties and about $5 \%$ for the new varieties. In summary, postharvest loss decreased significantly and therefore, the rural households were able to achieve a higher FVC output and increase their income levels.

The objectives of this paper are twofold: First, what are the determinants of the adoption of these upgrading strategies? Second, how do the upgrading strategies impact the well-being of Tanzanian households? Distinct from the huge number of studies that already exist on determinants of agricultural technologies $[15,16,18-20,25,26]$, this study utilized the adaptive lasso to contribute to a more precise analysis of the determinants. To estimate the impact of upgrading strategies for rural farmers, propensity score matching was applied to control for hidden and self-selection bias.

\section{Data and Methodology}

\subsection{Study Area and Data Collection}

The United Republic of Tanzania had a human development index of 0.528 in 2019, which ranks the least developed East African Country on position 159 out of 189 in the world [42]. Tanzania has a diversified landscape, which results in highly variable local conditions [43]. This is also true for the study area (Figure 1). 


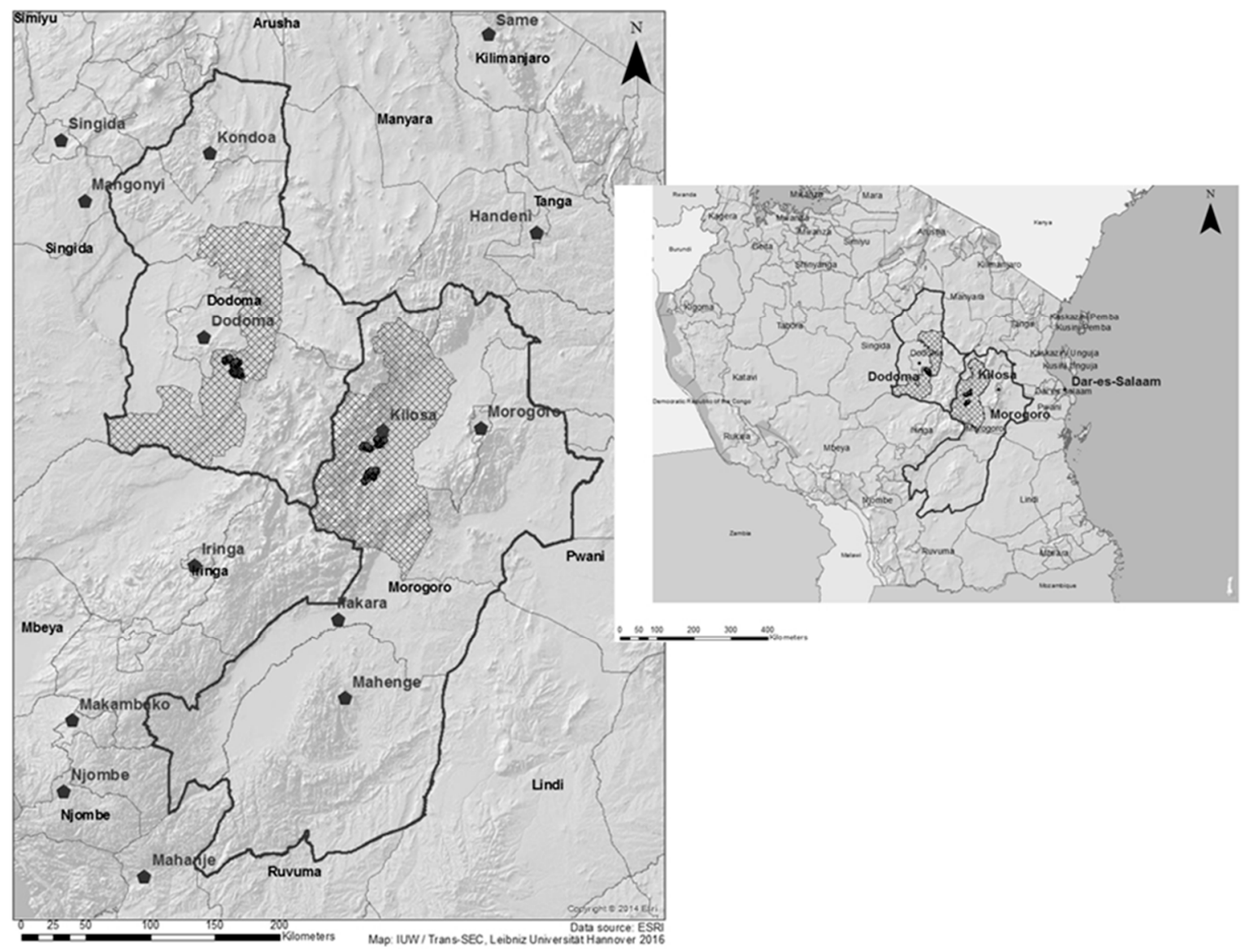

Figure 1. Location of Tanzania and the sample sites. Study sites are located in Kilosa district in Morogoro region and Chamwino district in Dodoma region (dashed area). Source: Own production using ArcGIS, Trans-Sec (2014).

Annex Table A1 illustrates key distinctions and economic and geographic characteristics of the two study sites. The first one, Dodoma depends on rain-fed farming, especially of millet and sorghum, which further contributes to low agricultural productivity [44]. Noteworthy is that Dodoma focuses on small-scale livestock keeping [45]. The main roads are poorly maintained [46] and the villages are often isolated from nearby markets and cities which hinder farmers from participating in trade. Almost every area in Tanzania was able to lower their level of poverty, but in Dodoma, it continuously increased, while simultaneously commercialization remained subsistence oriented [47]. The second region, Morogoro, is less dry and more diverse in terms of its food system [48]. The sample villages are more closely located to the large handling centre Dar es Salaam and the coast, which is favourable for rural farmers' trade. Nonetheless, the high dependence on agriculture and low level of commercialization in both regions are associated with low income levels.

The households for the survey were selected from the Kilosa district in Morogoro and the Chamwino district in Dodoma. The survey was conducted in 2016 and covered 820 households. In the two-step sampling procedure, six villages with homogeneous attributes were first chosen from the two heterogeneous regions. These villages include Ilakala, Changarawe, and Nyali in Kilosa and Ilolo, Idifu, and Ndebwe in Chamwino. The criteria for the selection process of the six villages are based on several comparable but differing socioeconomic and agroecological conditions [11]. In the second step, 150 households per village were randomly drawn based on household lists and proportionately to their subvillage size [11].

Before the survey, the maize-sheller, millet-thresher, and superbags were introduced to the farmers in the treatment villages. Additionally, farmers were provided with workshops and trainings for the respective innovations. Farmers could choose whether to adopt an UPS or not. Ndebwe and Nyali 
represent control villages without any interventions. While the maize-sheller was only introduced in Morogoro region, the farmers of Dodoma region only had the choice for the millet-thresher. The machinery devices intend to upgrade the FVC by reducing postharvest losses and increase the quality of the grains. Farmers use the machine once per year after harvest. Both the maize-sheller and millet-thresher are capital intense and require five to six people to operate [12]. To receive access to one of the machines, the farmers had to group up and develop a financial plan. They share the cost of the purchase (maize-sheller about 5,100,000 T.Sh and millet-thresher about 3,600,000 T.Sh), maintenance, and transport of the machine. The superbags increase the quality of grains and enable farmers to obtain competitive prices during lean seasons, as they can store their grain for longer time periods. The price of the bags range from 4000 to 10,000 T.Sh [13]. The household questionnaire covered several topics, including basic sociodemographic characteristics of household members, the perception of environmental shocks and changes in climatic conditions, such as precipitation rates. This is of specific interest since most Tanzanian farmers depend on rain-fed agriculture. The diverse income-generating activities, such as agricultural production, crop cultivation on farm size, off-farm employment, livestock earnings, and returns on capital assets, were surveyed as well. Of particular interest in this study are the value of crop production and the sales value of cultivated crops in determining the household commercialization index. To cover basic infrastructure-such as access to financial credit facilities, distances to markets for each village, and availability of extension services—a village questionnaire was additionally developed.

\subsection{Methodology}

\subsubsection{Adaptive Lasso to Identify Determinants of Adoption}

To identify factors that are associated with the decision to adopt an UPS, a three-step procedure is used $[49,50]$. In the first step, the variables that most likely influence the adoption decision need to be identified. In the second step, the adaptive lasso is then used to determine the factors of adoption, and in the third step, logistic regression models are applied. The binary logistic regression is applied due to the dichotomous nature of the dependent variable (adopter and nonadopter), while the multinomial logistic regression is applied allowing households to adopt more than one UPS. For the purpose of this study, an adopter was defined as a household that uses one of the three presented UPS. All other households that did not adopt the innovation were nonadopters.

For the first step, a summarizing list of the variables can be found in Annex Table A2. Nonetheless, it is unclear if every variable influences the decision to adopt an UPS in Tanzania. One of the major obstacles in microstudies with cross-sectional data is that most of the influencing factors for adoption of agricultural technologies are based on a specific regional context. However, often researchers use variables that have common acceptance in literature, even if it is not appropriate for each context and microstudy area [25]. Therefore, it seems reasonable to only use a subset of variables based on previous studies [51]. Indeed, including all 20 variables, which incorporate household-demographics, assets, social capital factors, climatic as well as geographic variables, and specific characteristics such as risk behaviour, awareness, and the perceived tenure status, would reduce the possibility of omitted variable bias. Nevertheless, in this case, the variance of the estimates would be high, which means that for different samples, the estimates will vary strongly with the result of inaccurate predictions. Therefore, as a remedy, this study uses a statistical model selection procedure, the adaptive lasso [51] given by:

$$
\left(\hat{\beta}_{0, A L}, \vec{\beta}_{A L}^{\prime}\right)^{\text {logistic }}=\underset{\beta_{0}, \vec{\beta}}{\operatorname{argmin}} \sum_{i=1}^{\mathrm{N}}-y_{i}\left(\beta_{0}+\dot{\vec{x}}_{i} \vec{\beta}\right)+\log \left(1+\exp \left(\beta_{0}+\dot{\vec{x}}_{i} \vec{\beta}\right)\right)+\lambda \sum_{j=1}^{\mathrm{J}} \hat{w}_{j}\left|\beta_{j}\right|
$$

This procedure is an extension of the lasso by Tibshirani [52], where $\dot{\vec{x}}_{i}=\left(x_{i, 1}, \ldots, x_{i, J}\right)^{\prime}$ is the $J$ linearly independent predictors, $\beta_{0}$ is the intercept, and $\vec{\beta}=\left(\beta_{1, \ldots} \beta_{\mathrm{J}}\right)$ is the parameter vector.

The important part of this equation is the regulation parameter $\lambda \geq 0$. It controls the amount of shrinkage applied to the estimates and is chosen using k-fold-cross-validation. If the regulation 
parameter is exactly $\lambda=0$, lasso nests the standard ordinary least squares estimation. When $\lambda$ increases, the coefficients continuously shrink towards zero, with the result that for very high $\lambda$, some coefficients are exactly zero. Variable selection and parameter estimation are executed simultaneously, meaning an increase in squared bias is thereby traded in for a larger decrease in variance of the estimates. As this paper considers a dichotomous classification, the dependent variable is binary. When applying a linear model to this problem, the probability of $y_{i}=1$ given, the values $\vec{x}_{i}$ are estimated. To ensure that the estimated probabilities of the dependent variable are in the interval [0,1], the logistic regression model can be used [18].

In addition to the ordinary lasso, it has weights $\dot{\vec{w}}=1 /\left|\dot{\vec{\beta}}_{j}\right|^{y}$ assigned to the coefficients. The weights are calculated by determining $\dot{\vec{\beta}}$ for the full set of explanatory variables using logistic regression. The adaptive lasso has consistency in variable selection for $J>2$ and asymptotic normality of the estimates, meaning the adaptive lasso fulfils the oracle property [51]. The results of the computation of the adaptive lasso is done in $\mathrm{R}$.

As a third step, binary and multinomial logistic regressions are applied to the subset of variables. After identifying factors that influence the adoption decision with the adaptive lasso, the logistic regression detects the magnitude and direction of the factors. It can be represented as follows $[53,54]$ :

$$
\mathrm{E}\left(\mathrm{y}_{\mathrm{i}} \mid \overrightarrow{\mathrm{x}}_{\mathrm{i}}\right)=\operatorname{Pr}\left(\mathrm{y}_{\mathrm{i}}=\mathrm{r} \mid \overrightarrow{\mathrm{x}}_{\mathrm{i}}\right)=\frac{1}{1+\exp \left(-\beta_{0}-\dot{\overrightarrow{\mathrm{x}}}_{\mathrm{i}} \vec{\beta}\right)}, \mathrm{r}=0,1,2,3, \mathrm{i}=1,2, \ldots, 820
$$

The binary model describes the probability of whether adoption has taken place $y_{i}=1$ or the alternative 1-Pr for nonadoption $y_{i}=0$. Since three UPS are used in this study, the multinomial logistic regression holds that $r=\{1,2,3\}$, where $r=1$ corresponds to the probability that household $i$ adopts the first UPS, $r=2$ the second UPS, $r=3$ the third UPS, and $r=0$ corresponds to the case for no adoption.

The coefficients in the logistic regression model are estimated using the maximum likelihood estimation method. Furthermore, to determine the magnitude, direction, and likelihood, the marginal effects are calculated using the delta method [55]. Additionally, to test if the two independent samples correspond to the same distribution, the Wilcoxon (Mann-Whitney test) rank-sum test is used [56].

\subsubsection{Propensity Score Matching to Measure Impacts on Well-being of Rural Households}

Estimating the impact of UPS adoption on the well-being of rural farmers using observational data is not an easy task-because of the necessity to identify the counterfactual situation had they not adopted the UPS. This is due to the fact that the farmers are not randomly distributed across the two groups (adopters and nonadopters); rather they are systematically selected by developing agencies based on similar characteristics $[23,40]$. To overcome the selection bias in the results, this study uses propensity score matching (PSM) [57]. PSM is a common method used when a small treated group needs to be compared to a large control group as it is the case in this study [58,59]. This study uses observational cross-sectional data, where the surveyed households declared if they adopted a certain UPS or not. It is impossible that the same household is observed with and without the adoption of a certain UPS at the same time.

The basic idea of PSM in this study is to build up groups of explanatory variables. Each group possesses relatively similar characteristics with the only difference being the adoption decision. Therefore, the outcome for each household that received the treatment is compared to a similar household that did not received the treatment. To appraise the similarity of characteristics, the propensity score $\mathrm{p}\left(\dot{\vec{x}}_{\mathrm{i}}\right)$ is applied as a balancing score, describing the probability of being an adopter given the observed characteristics of $\dot{\vec{x}}_{i}$ [58]. Applying the adaptive lasso causes another beneficial effect. The variable selection model reduces the used variables, making it easier to build up groups with characteristics similar to those of the explanatory variables. Eliminating irrelevant variables is only useful when there is a clear census on the unrelated outcome [60]. 
After computing propensity scores, the average treatment effect on the treated based on propensity score matching can be estimated as follows [61]:

$$
\mathrm{ATT}^{\mathrm{PSM}}=\mathrm{E}\left\{\mathrm{E}\left[\mathrm{Y} 1 \mid \mathrm{A}=1, \mathrm{p}\left(\dot{\overrightarrow{\mathrm{x}}}_{\mathrm{i}}\right)\right]-\mathrm{E}\left[\mathrm{Y} 0 \mid \mathrm{A}=0, \mathrm{p}\left(\dot{\overrightarrow{\mathrm{x}}}_{\mathrm{i}}\right)\right] \mid \mathrm{A}=1\right\}
$$

where (Y1) is an outcome variable in the form of an income indicator for a specific household which is compared to a similar household outcome (Y0). For $\mathrm{A}=1$, the household received the treatment meaning that it adopted an UPS, while for $\mathrm{A}=0$, it did not.

This study uses three different matching algorithms to calculate similar propensity scores following Caliendo and Kopeinig [57]. These include Nearest Neighbour Matching (NNM), Kernel Based Matching (KBM), and Radius Caliper Matching (RCM). For NNM, the five nearest neighbours of household adopters vs. nonadopters were matched with the most similar propensity scores. While simultaneously increasing the variance of the matches and reducing bias, the matching will be executed with replacements, meaning that nonadopters can be used more than once $[57,62]$. If the distance between households becomes too large, it will likely result in bad matches. To circumvent this risk, RCM is suggested as an altered approach. RCM only includes control units within the given propensity score caliper of 0.01 [63]. KBM utilizes weighted averages to compose the counterfactual outcome. Higher weights are allocated to those with a propensity score close to the treated observations and vice versa. Figure 2 displays propensity score distribution and common support areas. Lastly, Rosenbaum boundaries were calculated as a robustness check. The boundaries identify hidden biases caused by possible unobservable factor heterogeneity. The hidden bias adjusts for the chance to receive the treatment by a factor $\Gamma \geq 1$ and misstates the implication about the ATT [64].
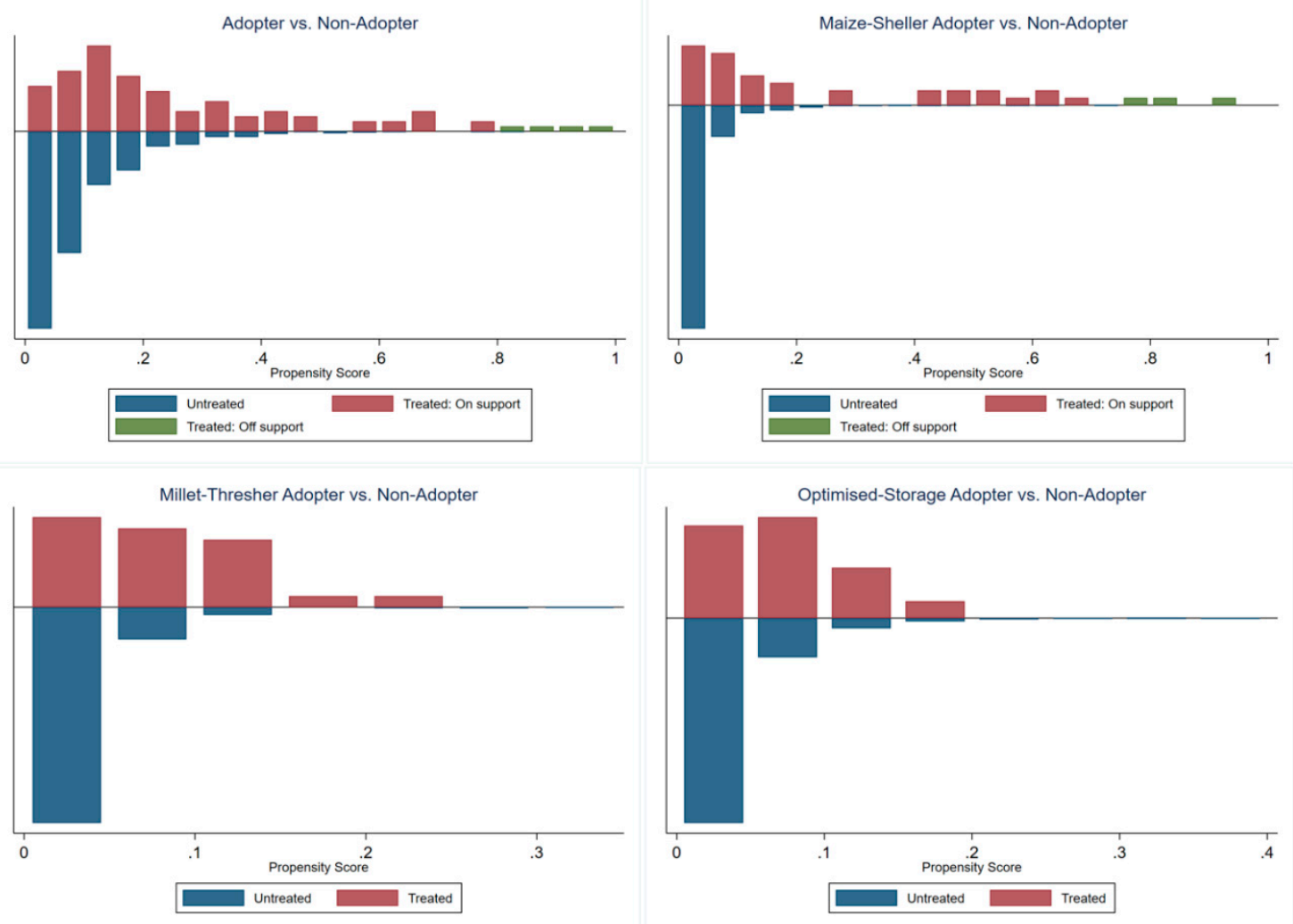

Figure 2. Propensity score distribution and common support for treated and untreated groups. Source: Own calculation based on Trans-SEC data (2014).

The impact variables of the three UPS and their expected impact on the well-being of rural farmers are presented in Table 1 based on previous literature presented in Section 1. 
Table 1. Well-being indicators.

\begin{tabular}{|c|c|c|c|}
\hline Variable & Description & Exp. Direction & Source \\
\hline Total annual net income & $\begin{array}{l}\text { Total available net income of } \\
\text { household (PPP US \$ 2010) }\end{array}$ & + & $\begin{array}{c}\text { Graef et al.; Shiferaw } \\
{[11,41]}\end{array}$ \\
\hline Income from crops & $\begin{array}{l}\text { Income generated from crops } \\
\text { (PPP US \$ 2010) }\end{array}$ & + & Kassie et al. [65] \\
\hline Postharvest loss & $\begin{array}{c}\text { Loss after harvest of crops and } \\
\text { grains in } \%\end{array}$ & - & $\begin{array}{l}\text { Bokusheva et al.; } \\
\text { Tefera }[66,67]\end{array}$ \\
\hline $\begin{array}{l}\text { Household Commercia-lization } \\
\text { Index (HCI) }\end{array}$ & $\begin{array}{c}1=\text { fully commercialized } 0= \\
\text { fully subsistence-oriented }\end{array}$ & + & Carletto et al. [68] \\
\hline Total value of durable goods & $\begin{array}{l}\text { accounts for goods with } \\
\text { durability }<1 \text { year }\end{array}$ & + & $\begin{array}{l}\text { Amare et al.; Asfaw } \\
\text { et al. }[23,40]\end{array}$ \\
\hline
\end{tabular}

\section{Results and Discussion}

\subsection{Characteristics of Adoption}

As illustrated in Annex Table A3, 91 households adopted the maize-sheller, millet-thresher, or storage superbags, representing approximately $11 \%$ of the whole population in the sample, while 729 did not adopt. About one-third of the adopters and about half of the 729 nonadopters are located in the Dodoma region. Although sociodemographic characteristics such as age, gender, or household size do not differ significantly between adopters and nonadopters, education and household assets such as asset score, farm size, and off-farm wage employment differ significantly. Adopters also differ most strongly from nonadopters with respect to social capital factors such as being a member in agricultural cooperatives. In addition, adopters have on average a higher awareness of changing soil fertility, they experienced more environmental shocks, and suffered from higher income losses due to shock in comparison to nonadopters.

Annex Table A4 reports differences between adopters and nonadopters regarding well-being indicators. Strong significant differences exist for the value of durable goods. Adopters in the Morogoro region have a significantly higher value of durable goods (75.26), in comparison to the nonadopters (25.67). In the Dodoma region, the adopters' value of durable goods is below average (25.43) for the adopters with a value of (13.98) as well for the nonadopters accounting for a value of (18.45). Furthermore, the HCI of the adopters is slightly higher than of the nonadopters in Morogoro but a lot higher than the average of the two sample sites. This indicates that FVCs in Morogoro are more developed than in Dodoma and that the component market interaction in the FVC are utilized with a higher density. In contrast, the descriptive results of the $\mathrm{HCI}$ in Dodoma indicate a rather subsistence-oriented agriculture. The total income from crop production in the two different regions does not seem to differ significantly between the adopters and nonadopters. Results indicate that Dodoma has lower income from crop production for adopters (372 PPP US \$) and for nonadopters (342 PPP US \$) than Morogoro and, furthermore, the incomes are below the average of the sample (414 PPP US \$). Although the total annual income per HH does not differ significantly between adopters and nonadopters in Dodoma, the adopters in Morogoro are slightly better off than the nonadopters.

\subsection{Determinants of Adoption}

To analyse the determinants of the decision to adopt an UPS, the logistic regression with all variables, the adaptive lasso and the logistic regression with only a few selected variables are applied. The regression results are shown in Table 2. When comparing the three methods, it can be seen that nine out of eleven variables, which the adaptive lasso indicated to be relevant, are significant. Furthermore, the coefficients corresponding to these variables are similar for all three methods. The interpretation of the adaptive lasso coefficients is the same as in the logistic regression. The standard deviation of the parameters is, however, much smaller when using only the relevant 
variables. This emphasizes that the adaptive lasso works as intended. In the following, only the variables, which the adaptive lasso indicated to be relevant, are discussed.

With regard to off-farm wage employment, households that are additionally involved in off-farm activities outside the farming sector are significantly less likely $(-0.997)$ to adopt an UPS. These results are in contrast to the study of Ellis and Freeman [30] who reported that the off-farm income could act as an income buffer to diminish the constraint of obtaining high capital-intense agricultural technologies. Nevertheless, the results are reasonable since farmers who additionally generate income from off-farm activities are less dependent on agriculture and hence adopt less agriculture-intense UPS [31].

The logistic regression also indicates that a household shows a significantly lower probability of adoption (-0.921), if there is a higher awareness about changing soil fertility. This is not necessarily surprising because changing soil fertility can mean that it may change to the better or to the worse. If the soil quality changes to the worse, then the yields and, accordingly, the output are likely to decrease and the household might not want to invest into processing machines or storage bags. This result is expected to be different if the UPS would be related to any soil fertility-enhancing investments as in the case of Lee [32] and Afolami et al. [69]. Then, the probability of adoption would likely increase in order to halt the deterioration and degradation of the soil. If the above result, however, relates to the less likely event that the soil fertility changes to the better, the household is more likely to invest also in processing and storage facilities in anticipation of higher yields. Further research is needed to verify these assumptions.

Contrary to expectations, the results show, on the 5\% significance level, that the experience of environmental shocks is positively correlated with the decision to adopt. In an earlier study about improved processing methods in Ethiopia, Cavatassi et al. [37] found a negative relation between experiencing an environmental shock and adoption. However, the results indicate that farmers use adoption as an ex ante coping strategy to mitigate the climatic risks. In Tanzania, environmental shocks such as droughts or floods occur frequently. Especially, the semiarid Dodoma region is prone to droughts. Therefore, the adoption of UPS, especially of the storage superbags, helps rural farmers to cope because they can store their crops for a longer time period. Additionally, farmers are able to sustain their families with food, in case of flooding or storms that destroy their harvest.

As expected, being part of a microcredit group facilitates the likelihood (0.863) of adopting an UPS in our case study. On the one hand, this shows that social capital facilitates the adoption, especially since several investors are needed to make first, the financial plan and then, to buy any of the two processing machines as a group. Furthermore, the idea of a microcredit group is to enhance the access of poor farmers to financial capital. Being member in such a group may thus open the access to credit for such an investment. This is in line with findings from several studies, as access to credit helps rural dwellers overcome the constraint barrier of capital-intense resources, such as agricultural inputs and technologies of greater costs in the form of machinery devices $[18,25,70]$. At the same time, it has to be noted that a much higher proportion of adopters are members in microcredit groups but that the adoption rate is generally very low. The descriptive results of Annex Table A3 underline the importance of accessing credit in facilitating the adoption decision. Most households stated they did not adopt due to high costs. 
Table 2. Factors that influence the adoption decision of upgrading strategies (UPS) in Tanzania—estimates from logistic regression and the adaptive lasso.

\begin{tabular}{|c|c|c|c|c|c|}
\hline \multicolumn{6}{|l|}{ Adoption Variables } \\
\hline & \multirow{2}{*}{\multicolumn{2}{|c|}{$\begin{array}{c}\text { Logit Regression } \\
\text { (All Variables) }\end{array}$}} & \multirow{2}{*}{\multicolumn{2}{|c|}{$\begin{array}{c}\text { Logit Regression (Adaptive } \\
\text { Lasso) }\end{array}$}} & \multirow{3}{*}{$\begin{array}{c}\text { Adaptive Lasso } \\
\text { Computation }\end{array}$} \\
\hline & & & & & \\
\hline & \multicolumn{4}{|c|}{$\mathrm{N}=91$} & \\
\hline & Coef & m.e & Coef & m.e & $\vec{\beta}_{A L}$ \\
\hline $\mathrm{HH}$ head is male & $\begin{array}{c}0.067 \\
(0.342)\end{array}$ & $\begin{array}{c}0.052 \\
(0.272)\end{array}$ & - & - & - \\
\hline Age of $\mathrm{HH}$ head in years & $\begin{array}{c}0.01 \\
(0.008)\end{array}$ & $\begin{array}{c}0.007 \\
(0.006)\end{array}$ & - & - & - \\
\hline $\begin{array}{l}\text { Education years of } \\
\text { schooling HH head }\end{array}$ & -0.019 & -0.001 & - & - & - \\
\hline & $(0.044)$ & $(0.035)$ & & & \\
\hline Household size & $\begin{array}{l}-0.013 \\
(0.055)\end{array}$ & $\begin{array}{l}-0.001 \\
(0.004)\end{array}$ & - & - & - \\
\hline Livestock keeping & $\begin{array}{l}-0.427 \\
(0.319)\end{array}$ & $\begin{array}{l}-0.033 \\
(0.025)\end{array}$ & $\begin{array}{l}-0.404 \\
(0.311)\end{array}$ & $\begin{array}{c}-0.0323 \\
(0.024)\end{array}$ & -0.3677549 \\
\hline $\begin{array}{l}\text { Off-farm wage } \\
\text { employment }\end{array}$ & $-0.948^{* * *}$ & $-0.075^{* * *}$ & $-0.997^{* * *}$ & $-0.0798^{* * *}$ & -0.9905171 \\
\hline & $(0.29)$ & $(0.023)$ & $(0.277)$ & $(0.022)$ & \\
\hline Farm size & $\begin{array}{l}-0.015 \\
(0.091)\end{array}$ & $\begin{array}{l}-0.012 \\
(0.007)\end{array}$ & - & - & - \\
\hline Perceived land security & $\begin{array}{c}0.176 \\
(0.113)\end{array}$ & $\begin{array}{c}0.013 \\
(0.008)\end{array}$ & $\begin{array}{c}0.194 * \\
(0.11)\end{array}$ & $\begin{array}{c}0.01552 * \\
(0.008)\end{array}$ & 0.1453635 \\
\hline Awareness & $\begin{array}{c}-0.875^{* * *} \\
(0.32)\end{array}$ & $\begin{array}{l}-0.069^{* * *} \\
(0.025)\end{array}$ & $\begin{array}{l}-0.921^{* * *} \\
(0.322)\end{array}$ & $\begin{array}{l}-0.073^{* * *} \\
(0.025)\end{array}$ & -0.9037974 \\
\hline Asset Score & $\begin{array}{c}0 \\
(0.001)\end{array}$ & $\begin{array}{c}0 \\
(0)\end{array}$ & - & - & - \\
\hline Microcredit group & $\begin{array}{c}0.756^{* *} \\
(0.372)\end{array}$ & $\begin{array}{c}0.060^{* *} \\
(0.029)\end{array}$ & $\begin{array}{c}0.863^{* *} \\
(0.358)\end{array}$ & $\begin{array}{c}0.069^{* *} \\
(0.028)\end{array}$ & 0.8305872 \\
\hline Store for selling & $\begin{array}{c}0.533 \\
(0.434)\end{array}$ & $\begin{array}{c}0.042 \\
(0.034)\end{array}$ & $\begin{array}{c}0.525 \\
(0.414)\end{array}$ & $\begin{array}{c}0.042 \\
(0.033)\end{array}$ & 0.4643561 \\
\hline Collective processing & $\begin{array}{l}2.850 * * * \\
(0.447)\end{array}$ & $\begin{array}{c}0.226^{* * *} \\
(0.033)\end{array}$ & $\begin{array}{l}2.764^{* * *} \\
(0.437)\end{array}$ & $\begin{array}{c}0.221 * * * \\
(0.032)\end{array}$ & 2.7129524 \\
\hline Collective production & $\begin{array}{l}0.712^{*} \\
(0.372)\end{array}$ & $\begin{array}{l}0.056^{*} \\
(0.029)\end{array}$ & $\begin{array}{c}0.695^{*} \\
(0.36)\end{array}$ & $\begin{array}{l}0.055^{*} \\
(0.028)\end{array}$ & 0.6982264 \\
\hline Income loss due to shock & $\begin{array}{c}0.001 \\
(0.001)\end{array}$ & $\begin{array}{c}0.001 \\
(0.001)\end{array}$ & - & - & - \\
\hline $\begin{array}{c}\text { Experienced } \\
\text { environmental shock }\end{array}$ & $\begin{array}{l}0.977^{* *} \\
(0.387)\end{array}$ & $\begin{array}{l}0.077^{* *} \\
(0.031)\end{array}$ & $\begin{array}{l}0.865^{* *} \\
(0.384)\end{array}$ & $\begin{array}{l}0.069 * * \\
(0.03)\end{array}$ & 0.8168528 \\
\hline $\begin{array}{l}\text { Member in an agricultural } \\
\text { organization }\end{array}$ & $\begin{array}{l}0.894^{* * *} \\
(0.271)\end{array}$ & $\begin{array}{l}0.071^{* * *} \\
(0.022)\end{array}$ & $\begin{array}{l}0.988^{* * *} \\
(0.259)\end{array}$ & $\begin{array}{l}0.079 * * * \\
(0.021)\end{array}$ & 0.9699722 \\
\hline Prepared to take risk & $\begin{array}{l}0.047 \\
(0.05)\end{array}$ & $\begin{array}{c}0.003 \\
(0.003)\end{array}$ & - & - & - \\
\hline Distance to next market & $\begin{array}{c}0.012 \\
(0.011)\end{array}$ & $\begin{array}{c}0 \\
(0)\end{array}$ & - & - & - \\
\hline Located in Morogoro & $\begin{array}{c}0.328 \\
(0.309)\end{array}$ & $\begin{array}{c}0.026 \\
(0.024)\end{array}$ & $\begin{array}{l}0.460 * \\
(0.268)\end{array}$ & $\begin{array}{l}0.036^{*} \\
(0.021)\end{array}$ & 0.4145265 \\
\hline Constant & $\begin{array}{l}-4.308^{* * *} \\
(1.009)\end{array}$ & - & $\begin{array}{l}-3.495^{* * *} \\
(0.698)\end{array}$ & - & -3.3054075 \\
\hline Pseudo $\mathrm{R}^{2}$ & 0.205 & & 0.198 & & \\
\hline $\begin{array}{l}\text { Wald Chi squared } \\
\qquad(20 ; 11 ; 36)\end{array}$ & $102.54^{* * *}$ & & $93.69^{* * *}$ & & \\
\hline Prob $>\mathrm{Chi}^{2}$ & 0 & & 0 & & \\
\hline Log pseudolikelihood & -227 & & -229 & & \\
\hline $\mathrm{N}$ & 820 & & 820 & & \\
\hline
\end{tabular}

Standard error in parentheses; marginal effects are displayed for logistic regression; $\vec{\beta}_{A L}$ applied for the logistic regression and the multinomial logistic regression; $p$-value $p$-values: ${ }^{*} p<0.10,{ }^{* *} p<0.05,{ }^{* * *} p<0.01$. 
Our results further show that also other social network factors, such as being a member of an agricultural organization or doing collective processing activities for postharvest handling, both facilitate the adoption of UPS at the $1 \%$ significance level. Based on the innovation-diffusion theory, it has been shown that information spreads more easily and faster in such networks because the farmers constantly exchange new information and constraints to the technology itself diminishes. Furthermore, as mentioned above, social capital is likely to trigger such group investment as needed in the case of a processing machine because there is trust among the members and because it might be easier to get access to the needed investment. Additionally, collective processing activities enhance the learning process of postharvest handling. These findings are in line with those from Lee [32] and Kassie et al. [33] and also correspond to the earlier mentioned descriptive results in Annex Table A2, which highlight that adopters are significantly more engaged in social networks than nonadopters

The results of our analysis also show that living in the Morogoro region favours the likelihood of households to adopt an UPS (0.460). Living in Morogoro as compared to Dodoma increases the probability for adoption by approximately $4 \%$. This may indicate that the region around Morogoro offers higher diversity in terms of agroecological conditions and cultivation, higher productivity on average, and better access to markets. Indeed, these factors have been identified as the most important barriers for adoption as pointed out by a study in Nigeria [12]. Therefore, when a household is located at the Morogoro region, these barriers are on average lower than in Dodoma, and therefore, our farm households located in the Morogoro region are more likely to adopt an UPS than those from the Dodoma region.

The perceived land security status significantly favours the probability to adopt an UPS but only at the $10 \%$ level. This is feasible because the most frequent answers of the households on plot characteristics reveal that most of the plots are government owned and since Tanzania's development is relatively low in terms of political stability, the government plays a crucial role in everyday life. The district of Kilosa has been suffering, which is augmented by bloody land conflicts between pastoralists and crop farmers. Farmers that perceive their land as more secure are more willing to try out new agricultural technologies, thus, knowing that they can realize returns from their investments on several farm activities [9].

When running the multinomial logistic regression to further analyse the determinants of the three individual UPS, some further interesting insights are revealed Annex Table A5. First, the same variables turn significant as in the binary case but not for every UPS alike. Then, the social capital variables such as being a member in an agricultural organization or being involved in collective processing strongly favour the likelihood of adopting the millet-thresher and maize-sheller. According to the study conducted by Isham [21] and Barrett [22], not only is the exchange of workers beneficial inside collective cooperatives but also the share and flow of information is higher than in noncooperatives. This enables farmers to take part in higher quality FVCs, which positively correlates with the likelihood of adoption. The nature of the collective activity seems to be dependent on the specific UPS, because for storage superbags adopters only, collective production is significant at the $1 \%$ level. This indicates that each UPS is different in usage and one needs to consider regional and local farmer's needs [32]. As expected, the higher experience of an income loss due to a shock increases the probability to adopt the superbags (0.002). This result support the hypothesis that the farmers act either proactively with long-term strategies to avoid losing more fractions of their anyhow subsistence-oriented FVC, or act only reactively, which yields to the same result of preventing upcoming loss [38].

\subsection{Upgrading Strategies to Improve the Agriculture Value Chains}

To assess the impact of UPS adoption, the households that adopted are compared to nonadopters based on indicators covering the well-being of rural households. The assessment is performed through the average treatment effect on the treated (ATT) based on PSM. As a robustness check, the ATT ${ }^{\text {PSM }}$ is estimated using three matching algorithms, including NNM, RCM, and KBM. For the case of multinomial adoption, the common support condition, kernel density plots are used to assess the 
probability of receiving each treatment level for all observations. The kernel density plot Annex Figure A1 suggests sufficient overlap among the treatment levels, despite a slightly left-skewed distribution for the treatment millet-thresher and storage superbags.

Assessing the impact of UPS adoption, the results for the ATT in Table 3 demonstrate that the adopter of the three presented UPS have a significant higher well-being than nonadopters. Table 3 provides evidence that the calculated ATT of NNM adopters are slightly better off in terms of value of durable goods (18.25), with a significance level of $10 \%$. If the value of durable goods increases, more expenditure on the consumption of durable goods is spent, which further indicates a better well-being of the rural households. This would suggest that the additional income generated out of the increased output by adopting UPS is rather spent on primary needs to sustain sufficient nutrition. Therefore, according to Maslow (1943), primary needs need to be satisfied first before realizing higher overall improvement. The well-being impact results on consumption expenditures on durable goods match the studies conducted by Afolami et al. [69], Amare et al. [23], as well as Asfaw et al. [40]. This finding is highly important because UPS are not only process-enhancing innovations but they also consider the whole improvement sequence of an agricultural FVC.

Table 3. Propensity score matching: the impact of UPS adoption on well-being in Tanzania.

\begin{tabular}{|c|c|c|c|c|c|c|c|}
\hline & \multicolumn{2}{|c|}{$\begin{array}{c}\text { Nearest } \\
\text { Neighbour }\end{array}$} & \multicolumn{2}{|c|}{ Radius } & \multicolumn{2}{|c|}{ Kernel } & \multirow[t]{2}{*}{$\Gamma$} \\
\hline & ATT & S.E & ATT & S.E & ATT & S.E & \\
\hline Adopter vs. Nonadopter & \multirow{2}{*}{62.26} & \multirow{2}{*}{384.24} & \multirow{2}{*}{201.66} & \multirow{2}{*}{323.80} & \multirow{2}{*}{125.43} & \multirow{2}{*}{337.8} & \\
\hline $\begin{array}{l}\text { Total annual net income per } \mathrm{HH} \\
\text { (PPP \$2010) }\end{array}$ & & & & & & & \\
\hline $\begin{array}{l}\text { Total net income from crop production per } \\
\text { HH (PPP \$2010) }\end{array}$ & -126.95 & 120.11 & 12.61 & 113.27 & -95.18 & 110.79 & \\
\hline Total value of durable goods per $\mathrm{HH}$ & $18.25 *$ & 9.49 & 10.91 & 8.64 & 9.62 & 10.17 & - \\
\hline $\mathrm{HCI}$ per $\mathrm{HH}$ & 0.03 & 0.044 & 0.056 & 0.038 & 0.02 & 0.033 & \\
\hline$\%$ of postharvest loss & 0.008 & 0.017 & -0.004 & 0.016 & 0.13 & 0.012 & \\
\hline Maize-Sheller vs. Nonadopter & \multirow{2}{*}{66.36} & \multirow{2}{*}{575.22} & \multirow{2}{*}{73.90} & \multirow{2}{*}{722.71} & \multirow{2}{*}{-42.12} & \multirow{2}{*}{703.54} & \\
\hline $\begin{array}{l}\text { Total annual net income per } \mathrm{HH} \\
\text { (PPP \$2010) }\end{array}$ & & & & & & & \\
\hline $\begin{array}{l}\text { Total net income from crop production per } \\
\text { HH (PPP \$2010) }\end{array}$ & -132.53 & 230.63 & -81.67 & 254.46 & -119.19 & 290.41 & \\
\hline Total value of durable goods per $\mathrm{HH}$ & $35.09 *$ & 21.08 & $34.29 *$ & 18.67 & 26.67 & 26.87 & 3.6 \\
\hline $\mathrm{HCI}$ per $\mathrm{HH}$ & $0.11 *$ & 0.067 & $0.14^{* *}$ & 0.071 & $0.13 * *$ & 0.062 & 3.5 \\
\hline$\%$ of postharvest loss & 0.048 & 0.035 & 0.053 & 0.034 & 0.05 & 0.034 & \\
\hline Millet-Thresher vs. Nonadopter & \multirow{2}{*}{-51.93} & \multirow{2}{*}{796.24} & \multirow{2}{*}{328.32} & \multirow{2}{*}{571.59} & \multirow{2}{*}{546.73} & \multirow{2}{*}{505.55} & \\
\hline $\begin{array}{l}\text { Total annual net income per } \mathrm{HH} \\
\text { (PPP \$2010) }\end{array}$ & & & & & & & \\
\hline $\begin{array}{l}\text { Total net income from crop production per } \\
\text { HH (PPP \$2010) }\end{array}$ & -14.57 & 185.48 & 51.84 & 176.65 & -8.46 & 154.08 & \\
\hline Total value of durable goods per $\mathrm{HH}$ & -28.02 & 19.31 & -18.24 & 12.57 & -17.84 & 13.99 & \\
\hline $\mathrm{HCI}$ per $\mathrm{HH}$ & $-0.18 * *$ & 0.077 & $-0.14^{* *}$ & 0.073 & $-0.16^{* *}$ & 0.060 & 3.4 \\
\hline$\%$ of postharvest loss & -0.005 & 0.018 & -0.006 & 0.011 & -0.011 & 0.010 & \\
\hline Optimized Storage vs. Nonadopter & \multirow[t]{2}{*}{-577.55} & \multirow[t]{2}{*}{380.65} & \multirow[t]{2}{*}{-193.17} & \multirow[t]{2}{*}{246.32} & \multirow[t]{2}{*}{-164.6} & \multirow[t]{2}{*}{233.82} & \\
\hline $\begin{array}{l}\text { Total annual net income per } \mathrm{HH} \\
\text { (PPP \$2010) }\end{array}$ & & & & & & & \\
\hline $\begin{array}{l}\text { Total net income from crop production per } \\
\text { HH (PPP \$2010) }\end{array}$ & -184.72 & 182.12 & -120.05 & 166.13 & -96.00 & 141.14 & \\
\hline Total value of durable goods per $\mathrm{HH}$ & 4.37 & 13.88 & 4.67 & 13.73 & 8.67 & 11.47 & \\
\hline $\mathrm{HCI}$ per $\mathrm{HH}$ & 0.06 & 0.076 & 0.05 & 0.058 & 0.05 & 0.065 & \\
\hline$\%$ of postharvest loss & -0.016 & 0.16 & $-0.02 *$ & 0.10 & $-0.016^{*}$ & 0.01 & 4.4 \\
\hline
\end{tabular}

ATT: average treatment effect on the treated; ${ }^{*} p<0.1{ }^{* *} p<0.05,{ }^{* * *} p<0.01$ when compared to nonadopting farmers; S.E.: bootstrapped standard errors; $\Gamma$ : Rosenbaum bounds (critical level for hidden bias). 
Taking a closer look at each UPS separately gives a clearer picture of the dynamics and impact of adopting UPS in Tanzania. For all three matching algorithms, the adoption of the maize-sheller has a positive and significant ATT for the HCI at the 5\% level for RCM as well as KM and 10\% for NNM. Adopters of the machinery device maize-sheller improve the process of shelling, therefore, increasing the amount produced for maize with the same amount of input. Following this, the UPS triggers the FVC process that further allows selling more at markets and achieving higher prices for the crops. The higher HCI indicates that more of the grains shelled by the adoption of a maize-sheller is traded at local spot markets or handling centres. The Morogoro region is especially favoured by the geographical proximity next to Dar es Salam. Then again, the increase of the HCI might lead to more economic surplus, resulting in higher income, which is further spent on durable goods, again increasing the well-being of rural households. This is confirmed by the statistical significance for the adoption of the maize-sheller on the value of durable goods for NNM and RCM. The results are consistent with a study conducted by Carletto et al. [68], who measured the degree of commercialization. The study concludes the positive linkage between increased commercialization and improved nutritional status, which reflects the results of the adoption of maize-sheller in this study [68]. Nonetheless, the results of the ATT for NNM at the $5 \%$ level for the HCI (-0.18) suggest that for the millet-thresher adopters in Dodoma region, especially, market infrastructures are dysfunctional, meaning the UPS cannot embrace its full potential.

Regarding storage superbags adopters, the ATT shows a significantly negative impact for RCM and KM at the $10 \%$ level. Adopters of this UPS have approximately $2 \%$ lower postharvest losses. As expected, the results suggest that the superbags decrease the postharvest losses due to the nature of the innovation $[67,71]$. The superbags enhance the quality of the grains because they are not affected by insects or pesticides. Accordingly, the outcome of the FVC is increased in terms of higher income generated when selling the grains at local spot markets. [12]. Nonetheless, even if the postharvest losses decrease, it does not reflect an increase in higher income or better well-being. The result itself does not show a clear relation to the crops produced. If the farmers do not produce sufficient staple crops, the reduction is not that high to achieve the overall goal of improved well-being.

Regarding the influence of hidden bias represented by $\Gamma$, Table 3 lists the Rosenbaum bounds for all significant results. The results concerning total value of durable goods are very robust against hidden bias, since even a three-fold increase of hidden bias does not affect their significance. To continue, the same holds true for the HCI index per household as well as percentage loss of postharvest handling.

\section{Summary and Conclusions}

This study evaluated the determinants of adopting an upgrading strategy and their potential impacts on household well-being measured by different indicators in rural Tanzania. The analysis used cross-sectional data collected from 820 farm households in Tanzania. In order to investigate factors that influenced the adoption decision, the adaptive lasso was utilized. The causal impact of UPS adoption was then estimated by using the average treatment effect on the treated with propensity score matching. This allowed the estimation of a more accurate effect of UPS adoption on well-being of the households by controlling for the selection bias.

Results of the adaptive lasso highlighted the importance of social capital variables for the likelihood of adopting UPS. Particularly, collective processing and production as well as membership in an agriculture-related organization act as the main factors circumventing constraints to UPS adoption. This suggests that the promotion of social capital is pivotal in enhancing the adoption of innovations and technologies in the farming sector. However, further research on a more detailed differentiation of social network factors is necessary for developing a clearer understanding of how the information exchange of farmers can be used more effectively. In addition, access to credit has been found to be of great importance for promoting technology adoption. Poor farmers without adequate collateral tend to be excluded from formal financial services due to high transaction costs and incomplete information. Thus, financial institutions hesitate to offer them services. Consequently, poor farmers may not be 
able to invest in new technologies and agricultural productivity-enhancing activities. With respect to the factor "Awareness" (-0.921) about changing soil fertility, further research is needed to better understand the direction of the changes. If farmers are aware of a declining soil fertility, then it is understandable that they have no interest in investing into processing technologies as they are likely to expect declining yields in the future. At the same time, the government should offer UPS to improve soil fertility. Such an innovation is then more likely to be taken up by the farmers.

The impact estimation of the PSM revealed that the adoption of UPS has a significant positive impact on household well-being in rural Tanzania. Results confirmed that the three UPS have a positive impact on the value of durable goods, although the results are not consistent for each UPS separately. This demonstrates the importance of differentiating each UPS individually. The results generally highlighted the potential role of UPS in enhancing rural household welfare, as indicated by the HCI, which should eventually result in higher income. This would translate into higher food security, lower poverty levels and greater ability to withstand environmental risks.

Despite the comprehensiveness of the data, it cannot account for time-varying influences. Therefore, panel data is needed. Furthermore, as already mentioned, another limitation to this study is the limited adoption rate by participants throughout the questionnaire. Therefore, the results of the determinants as well as for the impact need to be approached with caution. Moreover, the definition of an adopter in the present study could lead to the misinterpretation of the impact of individual UPS, because households were able to adopt multiple UPS in addition to the three examined ones.

Nonetheless, the beneficial outcomes of adopting UPS raise the question why such a high proportion of rural households in Tanzania did not adopt UPS. Furthermore, it poses the question why households that adopted the improved machinery did not simultaneously adopt the improved bags to benefit from synergy effects. Overall, the analysis of the determinants of adoption identified lack of access to credit, absence of social networks and lack of information resulting in insufficient awareness as major key constraints to adoption of UPS. The results indicated possible policy interventions which enhance the adoption of UPS. Policy makers could create incentives for rural farmers to establish agricultural cooperatives, both financially and institutionally, to strengthen social capital and access to physical capital. Policy should also focus on the integration of rural farmers who have been unable to build sufficient social network links to increase agricultural productivity and welfare among them. Additionally, the government could improve infrastructure to make financial services more accessible or facilitate microcredit schemes to poor rural farmers. Extension services could promote awareness campaigns on UPS to improve soil fertility, combined with tailored information services on local farms' soil characteristics, enabling a policy mix that facilitates and accelerates adoption. Overall, a strategic approach of upgrading FVCs is indispensable for an effective and efficient improvement of rural farmer's livelihood in Tanzania.

Author Contributions: Conceptualization, J.S., K.B. and U.G.; methodology, J.S. and K.B.; formal analysis, J.S.; investigation, J.S. and K.B.; resources, J.S., K.B. and U.G.; data curation, J.S., K.B. and U.G.; writing-original draft preparation, J.S.; writing-review and editing, J.S., U.G. and K.B.; visualization, J.S.; supervision, K.B. and U.G.; project administration, K.B. and funding acquisition, U.G. All authors have read and agreed to the published version of the manuscript.

Funding: This research received no external funding.

Acknowledgments: This publication is a product of the project "Innovating Strategies to Safeguard Food Security using Technology and Knowledge Transfer: A People-centered Approach (TransSEC)" (http://www.trans-sec.org/) funded by the German Federal Ministry of Education and Research (BMBF) and cofinanced by the German Federal Ministry of Economic Cooperation and Development (BMZ). The views expressed are those of the authors and may not under any circumstances be regarded as stating an official position of the BMBF and BMZ.

Conflicts of Interest: The authors declare that they have no conflict of interest. 


\section{Appendix A}

Table A1. Basic characteristics of the two sample sites.

\begin{tabular}{|c|c|c|}
\hline Category & Chamwino-Dodoma Region & Kilosa-Morogoro Region \\
\hline Crop system & Based on sorghum and millet & $\begin{array}{l}\text { Based on maize, sorghum, legumes, rice, } \\
\text { and horticulture }\end{array}$ \\
\hline Commercialization & Subsistence & Subsistence to semi-commercial \\
\hline Poverty & GDP per capita 690,000 T.Sh, & GDP per capita 1,000,000 T.Sh. \\
\hline Highland & Flat plains and small hills & $\begin{array}{l}\text { Flat plains, highlands and more divers } \\
\text { dry alluvial valleys }\end{array}$ \\
\hline Livestock & Highly dependent on livestock & Partly dependent on livestock \\
\hline Climate & Semiarid $(350-500 \mathrm{~mm})$ & Predominantly subhumid $(600-800 \mathrm{~mm})$ \\
\hline Markets & $\begin{array}{l}\text { Bad infrastructure and weak market } \\
\text { access }\end{array}$ & $\begin{array}{l}\text { Medium infrastructure and weak } \\
\text { market access }\end{array}$ \\
\hline Productivity & Low to medium & Low to high \\
\hline Land pressure & Medium and high & High \\
\hline
\end{tabular}

Source: Own compilation based on [10,13].

Table A2. Summary of variables used in this study based on literature.

\begin{tabular}{|c|c|c|c|}
\hline Variables & Description & Exp. Direction & Source \\
\hline \multicolumn{4}{|l|}{$\begin{array}{c}\text { Household } \\
\text { Demographics }\end{array}$} \\
\hline gender & $1=$ If household head is male & $+/=/-$ & $\begin{array}{c}\text { Seymour et al.; Doss and } \\
\text { Morris }[24,72]\end{array}$ \\
\hline Age & Age of household head in years & $+/=/-$ & Kassie et al.; Feder et al. \\
\hline Education & $\begin{array}{l}\text { Years of schooling of household } \\
\text { head }\end{array}$ & + & $\begin{array}{c}\text { Amare et al.; Feder et al. } \\
{[18,23]}\end{array}$ \\
\hline Household size & $\begin{array}{l}\text { Number of nucleus household } \\
\text { members }\end{array}$ & + & $\begin{array}{c}\text { Adeyele et al.; Doss } \\
{[12,25]}\end{array}$ \\
\hline \multicolumn{4}{|l|}{ Household Assets } \\
\hline Asset score & Value of assets in USD (ratio) & + & $\begin{array}{c}\text { Teklewold; Morris } \\
{[28,59]}\end{array}$ \\
\hline Livestock & 1 = Household keeps livestock & - & Barrett [22] \\
\hline Farm size & $\begin{array}{l}\text { Size of agricultural land owned by } \\
\text { household (ha) }\end{array}$ & + & $\begin{array}{l}\text { Uaiene et al.; Feder et al. } \\
\qquad[18,26]\end{array}$ \\
\hline $\begin{array}{l}\text { Off-farm } \\
\text { wage-employment }\end{array}$ & $\begin{array}{l}1=\text { Household has off-farm } \\
\text { employment activities }\end{array}$ & $+/-$ & $\begin{array}{c}\text { Ellis and Freeman; } \\
\text { Goodwin and Mishra } \\
{[30,31]}\end{array}$ \\
\hline \multicolumn{4}{|l|}{$\begin{array}{l}\text { Household Social } \\
\text { Capital }\end{array}$} \\
\hline Microcredit group & $\begin{array}{l}1=\text { Household head is part of a } \\
\text { microcredit group }\end{array}$ & + & $\begin{array}{l}\text { Abdulai and Huffmann } \\
\text { [70] }\end{array}$ \\
\hline $\begin{array}{c}\text { Member in agricultural } \\
\text { organization }\end{array}$ & $\begin{array}{l}1=\text { Household head is member of } \\
\text { any agricultural organization }\end{array}$ & + & $\begin{array}{c}\text { Isham; Kassie et al. } \\
{[21,33]}\end{array}$ \\
\hline Store for selling & $1=$ Household stores for selling & + & Tefera [67] \\
\hline Collective processing & $\begin{array}{l}1=\text { Household does collective } \\
\text { processing }\end{array}$ & + & Lee [32] \\
\hline Collective production & $\begin{array}{l}1=\text { Household does collective } \\
\text { production }\end{array}$ & + & Lee [32] \\
\hline
\end{tabular}


Table A2. Cont.

\begin{tabular}{|c|c|c|c|}
\hline Variables & Description & Exp. Direction & Source \\
\hline \multicolumn{4}{|l|}{$\begin{array}{l}\text { Household Specific } \\
\text { Characteristics }\end{array}$} \\
\hline Awareness & $\begin{array}{l}1=\text { Household head is aware of } \\
\text { changing soil fertility (better or } \\
\text { worse) }\end{array}$ & + & Afolami et al. [69] \\
\hline Prepared to take risk & $\begin{array}{l}0=\text { Household head is absolutely } \\
\text { risk averse } 10=\mathrm{HH} \text { head is } \\
\text { willing to take risk }\end{array}$ & + & $\begin{array}{l}\text { Teklewold and Köhlin } \\
\text { [36] }\end{array}$ \\
\hline Perceived land security & $\begin{array}{l}\text { Perceived tenure status of land } \\
\text { security }(0=\text { not secure })-(3= \\
\text { very secure })\end{array}$ & + & Kassie et al. [9] \\
\hline \multicolumn{4}{|l|}{$\begin{array}{c}\text { Household Climate } \\
\text { Change }\end{array}$} \\
\hline $\begin{array}{c}\text { Experienced } \\
\text { environmental shock }\end{array}$ & $\begin{array}{l}1=\text { Household experienced } \\
\text { environmental shock }\end{array}$ & - & Cavatassi [37] \\
\hline Income loss due to shock & $\begin{array}{l}\text { Average on household income loss } \\
\text { due to environmental shock }\end{array}$ & - & Grothmann and Patt [38] \\
\hline \multicolumn{4}{|l|}{ Geographics } \\
\hline Distance to next market & $\begin{array}{l}\text { Distance from homestead to next } \\
\text { market }(\mathrm{km})\end{array}$ & - & $\begin{array}{l}\text { Mwangi and Kariuki; } \\
\text { Idrisa et al. }[34,73]\end{array}$ \\
\hline Located in Morogoro & $\begin{array}{l}1=\text { Household located in } \\
\text { Morogoro }\end{array}$ & + & URT [2] \\
\hline
\end{tabular}

Source: Own consideration based on previous studies.

Table A3. Summary statistics of rural farmer's adoption scheme in Tanzania.

\begin{tabular}{|c|c|c|c|c|c|c|}
\hline \multirow[t]{3}{*}{ Variable } & \multicolumn{3}{|c|}{ Pooled Sample } & \multicolumn{2}{|c|}{ By Subsample } & \multirow[b]{2}{*}{$\begin{array}{l}\text { Storage } \\
\text { Superbags }\end{array}$} \\
\hline & $\begin{array}{c}\text { Total } \\
\text { Sample }\end{array}$ & Adopter & Nonadopter & $\begin{array}{l}\text { Maize- } \\
\text { Sheller }\end{array}$ & $\begin{array}{l}\text { Millet- } \\
\text { Thresher }\end{array}$ & \\
\hline & $\mathrm{N}=820$ & $\mathrm{~N}=91$ & $\mathrm{~N}=729$ & $\mathrm{~N}=37(1)$ & $N=23(2)$ & $\mathbf{N}=31(3)$ \\
\hline \multicolumn{7}{|l|}{ Household Demographics } \\
\hline Gender ( 1 = HH head is male $)$ & $\begin{array}{c}0.76 \\
(0.42)\end{array}$ & $\begin{array}{l}0.79 \\
(0.4)\end{array}$ & $\begin{array}{c}0.76 \\
(0.42)\end{array}$ & $\begin{array}{c}0.91 * * \\
(0.28)\end{array}$ & $\begin{array}{c}0.74 \\
(0.45)\end{array}$ & $\begin{array}{c}0.67 \\
(0.47)\end{array}$ \\
\hline Age (HH head in years) & $\begin{array}{c}51.15 \\
(16.55)\end{array}$ & $\begin{array}{l}51.22 \\
(16.2)\end{array}$ & $\begin{array}{l}51.14 \\
(16.6)\end{array}$ & $\begin{array}{c}47.4 \\
(13.47)\end{array}$ & $\begin{array}{c}55.6 \\
(11.87)\end{array}$ & $\begin{array}{l}52.51 \\
(20.76)\end{array}$ \\
\hline Education (HH head years schooling) & $\begin{array}{c}4.55 \\
(3.44)\end{array}$ & $\begin{array}{c}5.22 * * * \\
(3.27)\end{array}$ & $\begin{array}{c}4.46 \\
(3.45)\end{array}$ & $\begin{array}{c}6.27^{* * *} \\
(2.7)\end{array}$ & $\begin{array}{c}4.47 \\
(3.19)\end{array}$ & $\begin{array}{c}4.51 \\
(3.67)\end{array}$ \\
\hline Household size (member) & $\begin{array}{c}5.25 \\
(2.35)\end{array}$ & $\begin{array}{c}5.27 \\
(2.51)\end{array}$ & $\begin{array}{c}5.24 \\
(2.32)\end{array}$ & $\begin{array}{c}5.46 \\
(1.79)\end{array}$ & $\begin{array}{c}5.13 \\
(2,00)\end{array}$ & $\begin{array}{c}5.16 \\
(3.48)\end{array}$ \\
\hline \multicolumn{7}{|l|}{ Household Assets } \\
\hline Asset score (PPP US \$ 2010) & $\begin{array}{c}58.87 \\
(125.86)\end{array}$ & $\begin{array}{l}74.4^{* * *} \\
(98.66)\end{array}$ & $\begin{array}{c}56.93 \\
(129.77)\end{array}$ & $\begin{array}{c}97.33^{* * *} \\
(114)\end{array}$ & $\begin{array}{l}82.27^{* *} \\
(119.19)\end{array}$ & $\begin{array}{c}41.18 \\
(36.78)\end{array}$ \\
\hline Livestock (1 = HH owns livestock) & $\begin{array}{c}0.8 \\
(0.39)\end{array}$ & $\begin{array}{c}0.75 \\
(0.43)\end{array}$ & $\begin{array}{c}0.81 \\
(0.39)\end{array}$ & $\begin{array}{c}0.76 \\
(0.43)\end{array}$ & $\begin{array}{c}0.96 \\
(0.21)\end{array}$ & $\begin{array}{c}0.61^{* * *} \\
(0.49)\end{array}$ \\
\hline Farm size (ha) & $\begin{array}{c}2.21 \\
(1.71)\end{array}$ & $\begin{array}{c}2.65^{* * *} \\
(1.58)\end{array}$ & $\begin{array}{c}2.16 \\
(1.72)\end{array}$ & $\begin{array}{c}2.94^{* * *} \\
(1.52)\end{array}$ & $\begin{array}{c}2.69^{* * *} \\
(1.4)\end{array}$ & $\begin{array}{c}2.26 \\
(1.74)\end{array}$ \\
\hline Off-farm wage employment ( 1 = yes $)$ & $\begin{array}{c}0.42 \\
(0.49)\end{array}$ & $\begin{array}{c}0.24^{* * *} \\
(0.43)\end{array}$ & $\begin{array}{c}0.44 \\
(0.49)\end{array}$ & $\begin{array}{l}0.27 \text { ** } \\
(0.45)\end{array}$ & $\begin{array}{l}0.08^{* * *} \\
(0.28)\end{array}$ & $\begin{array}{c}0.32 \\
(0.47)\end{array}$ \\
\hline
\end{tabular}


Table A3. Cont.

\begin{tabular}{|c|c|c|c|c|c|c|}
\hline \multirow[t]{3}{*}{ Variable } & \multicolumn{3}{|c|}{ Pooled Sample } & \multicolumn{2}{|c|}{ By Subsample } & \multirow[b]{2}{*}{$\begin{array}{l}\text { Storage } \\
\text { Superbags }\end{array}$} \\
\hline & $\begin{array}{c}\text { Total } \\
\text { Sample }\end{array}$ & Adopter & Nonadopter & $\begin{array}{l}\text { Maize- } \\
\text { Sheller }\end{array}$ & $\begin{array}{l}\text { Millet- } \\
\text { Thresher }\end{array}$ & \\
\hline & $\mathrm{N}=820$ & $\mathbf{N}=91$ & $\mathrm{~N}=729$ & $\mathrm{~N}=37(1)$ & $N=23(2)$ & $N=31(3)$ \\
\hline \multicolumn{7}{|l|}{ Household Social Capital } \\
\hline Access to credit $(1=$ yes $)$ & $\begin{array}{c}0.09 \\
(0.29)\end{array}$ & $\begin{array}{l}0.17^{* *} \\
(0.38)\end{array}$ & $\begin{array}{c}0.08 \\
(0.28)\end{array}$ & $\begin{array}{c}0.24^{* * *} \\
(0.44)\end{array}$ & $\begin{array}{c}0.13 \\
(0.34)\end{array}$ & $\begin{array}{c}0.13 \\
(0.34)\end{array}$ \\
\hline Member in organization (1 = yes) & $\begin{array}{c}0.37 \\
(0.48)\end{array}$ & $\begin{array}{l}0.59^{* * *} \\
(0.49)\end{array}$ & $\begin{array}{c}0.34 \\
(0.47)\end{array}$ & $\begin{array}{l}0.70^{* * *} \\
(0.46)\end{array}$ & $\begin{array}{l}0.65^{* * *} \\
(0.49)\end{array}$ & $\begin{array}{l}0.42 \\
(0.5)\end{array}$ \\
\hline Storing ( $1=\mathrm{HH}$ does store for selling) & $\begin{array}{l}0.89 \\
(0.3)\end{array}$ & $\begin{array}{c}0.92 \\
(0.26)\end{array}$ & $\begin{array}{l}0.89 \\
(0.3)\end{array}$ & $\begin{array}{c}0.89 \\
(0.31)\end{array}$ & $\begin{array}{l}1^{*} \\
(0)\end{array}$ & $\begin{array}{c}0.9 \\
(0.3)\end{array}$ \\
\hline $\begin{array}{l}\text { Collective processing }(1=\mathrm{HH} \text { does } \\
\text { collective processing })\end{array}$ & $\begin{array}{c}0.04 \\
(0.19)\end{array}$ & $\begin{array}{l}0.20^{* * *} \\
(0.4)\end{array}$ & $\begin{array}{c}0.01 \\
(0.13)\end{array}$ & $\begin{array}{l}0.38^{* * *} \\
(0.49)\end{array}$ & $\begin{array}{l}0.17^{* * *} \\
(0.38)\end{array}$ & $\begin{array}{c}0.03 \\
(0.18)\end{array}$ \\
\hline $\begin{array}{l}\text { Collective production }(1=\mathrm{HH} \text { does } \\
\text { collective production) }\end{array}$ & $\begin{array}{c}0.1 \\
(0.29)\end{array}$ & $\begin{array}{c}0.14 \\
(0.35)\end{array}$ & $\begin{array}{c}0.09 \\
(0.29)\end{array}$ & $\begin{array}{c}0.1 \\
(0.31)\end{array}$ & $\begin{array}{c}0.04 \\
(0.21)\end{array}$ & $\begin{array}{c}0.25^{* * *} \\
(0.44)\end{array}$ \\
\hline \multicolumn{7}{|l|}{ Household Specific Characteristics } \\
\hline Awareness ( 1 = yes) & $\begin{array}{c}0.45 \\
(0.43)\end{array}$ & $\begin{array}{c}0.30^{* * *} \\
(0.38)\end{array}$ & $\begin{array}{c}0.47 \\
(0.43)\end{array}$ & $\begin{array}{c}0.20^{* * *} \\
(0.33)\end{array}$ & $\begin{array}{c}0.52 \\
(0.43)\end{array}$ & $\begin{array}{c}0.25^{* * *} \\
(0.35)\end{array}$ \\
\hline $\begin{array}{l}\text { Risk attitude } \mathrm{HH} \text { head }(0=\text { fully risk } \\
\text { averse })(10=\text { fully prepared to take risk })\end{array}$ & $\begin{array}{c}5.56 \\
(2.73)\end{array}$ & $\begin{array}{l}6.21 * \\
(2.56)\end{array}$ & $\begin{array}{c}5.48 \\
(2.74)\end{array}$ & $\begin{array}{c}6.86^{* * *} \\
(2.2)\end{array}$ & $\begin{array}{c}6.34 \\
(2.51)\end{array}$ & $\begin{array}{c}5.35 \\
(2.82)\end{array}$ \\
\hline $\begin{array}{l}\text { Perceived land security }(0=\text { not secure at } \\
\text { all) }(3=\text { very secure })\end{array}$ & $\begin{array}{c}1.87 \\
(1.11)\end{array}$ & $\begin{array}{c}1.89 \\
(1.02)\end{array}$ & $\begin{array}{c}1.86 \\
(1.13)\end{array}$ & $\begin{array}{c}1.74 \\
(0.98)\end{array}$ & $\begin{array}{c}2.05 \\
(1.19)\end{array}$ & $\begin{array}{l}1.96 \\
(0.92)\end{array}$ \\
\hline \multicolumn{7}{|l|}{ Household Climate Effect } \\
\hline Environmental shock (1 = yes) & $\begin{array}{c}0.47 \\
(0.34)\end{array}$ & $\begin{array}{l}0.56^{*} \\
(0.34)\end{array}$ & $\begin{array}{c}0.46 \\
(0.33)\end{array}$ & $\begin{array}{l}0.63 * * \\
(0.33)\end{array}$ & $\begin{array}{c}0.41 \\
(0.38)\end{array}$ & $\begin{array}{c}0.59 * * \\
(0.31)\end{array}$ \\
\hline Income loss due to shock (PPP US \$ 2010) & $\begin{array}{c}708.1 \\
(971.92)\end{array}$ & $\begin{array}{l}106.5^{* * *} \\
(1318.6)\end{array}$ & $\begin{array}{c}663.5 \\
(910.91)\end{array}$ & $\begin{array}{l}1371.17^{* * *} \\
(1572.94)\end{array}$ & $\begin{array}{l}860.79^{*} \\
(978.13)\end{array}$ & $\begin{array}{c}853.44 \\
(1162.52)\end{array}$ \\
\hline \multicolumn{7}{|l|}{ Geographics } \\
\hline Distance to market (km) & $\begin{array}{c}9.55 \\
(11.31)\end{array}$ & $\begin{array}{c}12.27 \\
(14.77)\end{array}$ & $\begin{array}{c}9.21 \\
(10.77)\end{array}$ & $\begin{array}{l}13.24^{* *} \\
(17.2)\end{array}$ & $\begin{array}{c}6.56 \\
(2)\end{array}$ & $\begin{array}{c}15.35 \\
(16.14)\end{array}$ \\
\hline Region (1 = Morogoro) & $\begin{array}{l}0.48 \\
(0.5)\end{array}$ & $\begin{array}{l}0.66^{* * *} \\
(0.47)\end{array}$ & $\begin{array}{c}0.46 \\
(0.49)\end{array}$ & $\begin{array}{c}1^{* * *} \\
(0)\end{array}$ & $\begin{array}{c}0.00^{* * *} \\
(0)\end{array}$ & $\begin{array}{c}0.74^{* * *} \\
(0.44)\end{array}$ \\
\hline
\end{tabular}

Mean values (with standard deviation in parentheses) across schemes tested for statistically significant differences compared to nonadopting farmers using Mann-Whitney test; ${ }^{*} p<0.1,{ }^{* *} p<0.05,{ }^{* * *} p<0.01 / /$ Max VIF 1.45.

Table A4. Well-being indicators of rural farmers in Tanzania.

\begin{tabular}{lccccc}
\hline \multicolumn{1}{c}{ Variable } & \multicolumn{2}{c}{ Semi-arid Dodoma Region } & \multicolumn{2}{c}{ Semi-humid Morogoro Region } & Total Sample \\
\cline { 2 - 5 } & Adopter & Nonadopter & Adopter & Nonadopter & \multirow{2}{*}{$\mathbf{N}=\mathbf{8 2 0}$} \\
\cline { 2 - 4 } & $\mathbf{N = 3 1}$ & $\mathbf{N = 3 9 0}$ & $\mathbf{N}=\mathbf{6 0}$ & $\mathbf{N}=\mathbf{3 3 9}$ & \\
\hline HH well-being indicators & & & & 1405.35 \\
Total annual income per & 1657.12 & 1411.68 & $1764.47^{*}$ & 1311.49 & $(2221.26)$ \\
HH (PPP US \$ 2010) & $(1575.77)$ & $(1966.44)$ & $(2335.7)$ & $(2508.95)$ & 414.81 \\
Total income from crop & 372.55 & 342.45 & 447.39 & 496.15 & $(666.51)$ \\
production per HH (PPP & $(386.27)$ & $(496.41)$ & $(992.87)$ & $(771.02)$ & 25.43 \\
US \$ 2010) & 13.98 & 18,45 & $75.26 * * *$ & 25.67 & $(48.33)$ \\
Total value of durable & $(11.53)$ & $(35.19)$ & $(107.08)$ & $(41.37)$ & 0.028 \\
goods per HH & 0.016 & 0.021 & $0.057 * * *$ & 0.031 & $(0.07)$ \\
Percentage of postharvest & $(0.31)$ & $(0.06)$ & $(0.13)$ & $(0.08)$ & 0.3 \\
loss & 0.13 & 0.17 & $0.50 *$ & 0.44 & $(0.29)$ \\
HCI per HH & $(0.16)$ & $(0.22)$ & $(0.29)$ & $(0.28)$ & \\
\hline
\end{tabular}

Mean values (with standard deviation in parentheses) across schemes tested for statistically significant differences compared to nonadopting farmers using Mann-Whitney test; ${ }^{*} p<0.1,{ }^{* *} p<0.05,{ }^{* * *} p<0.01$. 
Table A5. Factors that influence the adoption decision of UPS in Tanzania-estimates from multinomial logistic regression and the adaptive lasso.

\begin{tabular}{|c|c|c|c|c|c|c|}
\hline \multirow{6}{*}{ Adoption Variables Base $=0$} & & & \multirow{2}{*}{\multicolumn{4}{|c|}{$\begin{array}{c}\text { Multinomial Logistic Regression } \\
\text { (Adaptive Lasso) }\end{array}$}} \\
\hline & \multirow{2}{*}{\multicolumn{2}{|c|}{ Maize-Sheller }} & & & & \\
\hline & & & \multicolumn{2}{|c|}{ Millet-Thresher } & \multicolumn{2}{|c|}{ Storage Superbags } \\
\hline & \multicolumn{2}{|l|}{1} & \multicolumn{2}{|l|}{2} & \multicolumn{2}{|c|}{3} \\
\hline & \multicolumn{2}{|c|}{ Adopter $\mathbf{N}=37$} & \multicolumn{2}{|c|}{ Adopter $\mathbf{N}=23$} & \multicolumn{2}{|c|}{ Adopter N = 31} \\
\hline & Coef & $\vec{\beta}_{A L}$ & Coef & $\vec{\beta}_{A L}$ & Coef & $\vec{\beta}_{A L}$ \\
\hline $\mathrm{HH}$ head is male & $\begin{array}{c}1.524 \\
(0.936)\end{array}$ & 1.38 & $\begin{array}{l}-0.106 \\
(0.515)\end{array}$ & -0.012 & $\begin{array}{c}-0.6 \\
(0.395)\end{array}$ & -0.468 \\
\hline Age of $\mathrm{HH}$ head in years & $\begin{array}{l}- \\
-\end{array}$ & - & $\begin{array}{l}- \\
-\end{array}$ & - & - & - \\
\hline $\begin{array}{l}\text { Education years of schooling } \\
\mathrm{HH} \text { head }\end{array}$ & - & - & - & - & - & - \\
\hline Household size & $\begin{array}{c}0.068 \\
(0.069)\end{array}$ & 0.042 & $\begin{array}{l}-0.169 \\
(0.106)\end{array}$ & -0.125 & $\begin{array}{c}0.041 \\
(0.083)\end{array}$ & 0 \\
\hline Livestock keeping & - & & & & & \\
\hline Off-farm wage employment & $\begin{array}{l}- \\
-\end{array}$ & - & - & - & $\begin{array}{l}- \\
-\end{array}$ & - \\
\hline & - & - & - & - & - & - \\
\hline Farm size (ha) & - & & - & & - & \\
\hline & - & - & - & - & - & - \\
\hline Perceived land security & - & & - & & - & \\
\hline & - & - & - & - & - & - \\
\hline Awareness & - & & - & & - & \\
\hline & - & - & - & - & - & - \\
\hline Asset score & - & & - & & - & \\
\hline & - & - & - & - & - & - \\
\hline Microcredit group & - & & - & & - & \\
\hline & - & - & - & - & - & - \\
\hline Store for selling & - & & - & & - & \\
\hline & - & - & - & - & - & - \\
\hline Collective processing & $\begin{array}{c}3.384 * * * \\
(0.576)\end{array}$ & 1.555 & $\begin{array}{l}2.478^{* * *} \\
(0.75)\end{array}$ & 0.641 & $\begin{array}{c}0.382 \\
(0.848)\end{array}$ & -0.641 \\
\hline Collective production & $\begin{array}{c}0.318 \\
(0.672)\end{array}$ & 0.153 & $\begin{array}{l}-0.469 \\
(1.067)\end{array}$ & -0.436 & $\begin{array}{c}1.204^{* * *} \\
(0.428)\end{array}$ & 1.022 \\
\hline Income loss due to shock & $\begin{array}{c}0.002 \\
(0.001)\end{array}$ & 0.008 & $\begin{array}{l}0.002 * \\
(0.001)\end{array}$ & 0.002 & $\begin{array}{c}0.005 \\
(0.002)\end{array}$ & -0.002 \\
\hline $\begin{array}{l}\text { Experienced environmental } \\
\text { shock }\end{array}$ & $1.393 *$ & 0.692 & 0.093 & -0.445 & $1.184^{* *}$ & 0.445 \\
\hline & $(0.768)^{*}$ & & $(0.766)$ & & $(0.571)$ & \\
\hline $\begin{array}{l}\text { Member in any agricultural } \\
\text { organization }\end{array}$ & $0.997^{* *}$ & 0.356 & $1.208^{* *}$ & 0.63 & 0.274 & -0.356 \\
\hline Prepared to take risk & $\begin{array}{c}(0.462) \\
0.084 \\
(0.084)\end{array}$ & 0.034 & $\begin{array}{c}(0.491) \\
0.154 \\
(0.099)\end{array}$ & 0.065 & $\begin{array}{l}(0.384) \\
-0.019 \\
(0.071)\end{array}$ & -0.039 \\
\hline Distance to next market & - & & - & & - & \\
\hline Located in Morogoro & $\begin{array}{c}17.60 * * * \\
(0.351)\end{array}$ & 2.42 & $\begin{array}{c}-18.04^{* * *} \\
(0.35)\end{array}$ & -3.329 & $\begin{array}{c}1.246^{* * *} \\
(0.438)\end{array}$ & 0.425 \\
\hline Constant & $\begin{array}{l}-24.07^{* * * *} \\
(2.281)\end{array}$ & -4.793 & $\begin{array}{l}-3.712 * * * \\
(1.218)\end{array}$ & 4.938 & $\begin{array}{l}-4.593^{* * * *} \\
(0.894)\end{array}$ & -0.138 \\
\hline Pseudo $\mathrm{R}^{2}$ & 0.264 & & & & & \\
\hline Wald Chi squared $(20 ; 11 ; 36)$ & $14,990.16^{* * *}$ & & & & & \\
\hline Prob $>\mathrm{Chi}^{2}$ & 0.000 & & & & & \\
\hline Log pseudolikelihood & -282.75 & & & & & \\
\hline $\mathrm{N}$ & 820 & & & & & \\
\hline
\end{tabular}

Standard error in parentheses; marginal effects are displayed for Logistic regression; $\vec{\beta}_{A L}$ applied for the logistic regression and the multinomial logistic regression; $p$-values: ${ }^{*} p<0.10,{ }^{* *} p<0.05,{ }^{* * *} p<0.01$. 


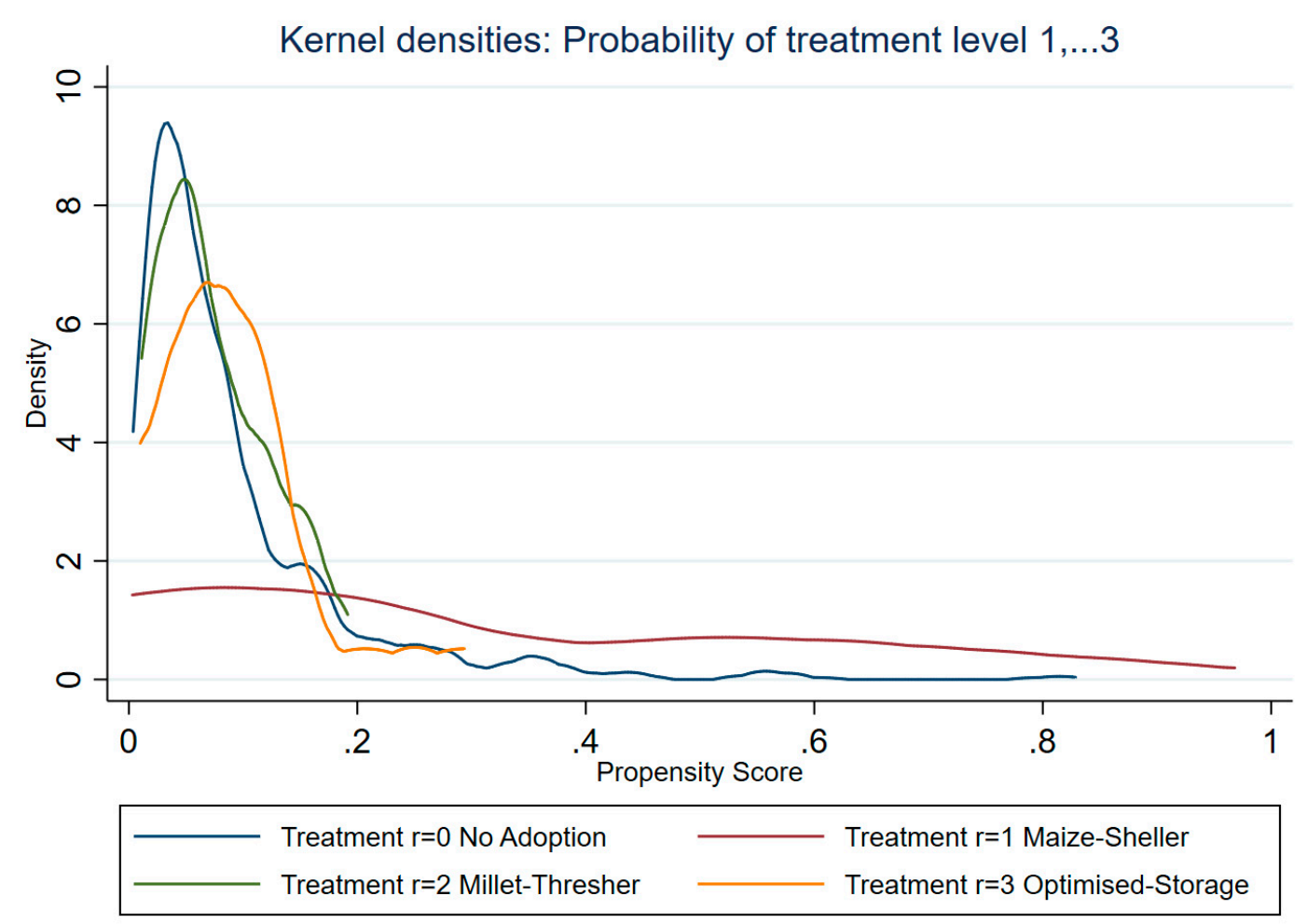

Figure A1. Kernel densities of the probability of treatment level $r=1, \ldots, 3$. Note: Matching on Nearest Neighbour Matching (NNM) for upgrading strategies (UPS) [1,2,3] and binary case [0,1].

\section{References}

1. African Union Inaugural Biennial Review Report of the African Union Commission on the Implementation of the Malabo Declaration on Accelerated Agricultural Growth and Transformation for Shared prosperity and Improved Livelihoods. Available online: http://www.donorplatform.org/news-caadp/au-summit-1stbiennial-review-on-the-status-of-agriculture-in-africa-triggers-unique-momentum-249.html (accessed on 19 August 2019).

2. United Nations Development Programme (UNDP); United Republic of Tanzania (URT). Tanzania Human Development Report 2017. Social Policy in the Context of Economic Transformation; Economic and Social Research Foundation: Dar es Salaam, Tanzania, 2017; Available online: http://hdr.undp.org/sites/default/ files/thdr2017launch.pdf (accessed on 5 May 2019).

3. FAO. Addressing marketing and processing constraints that inhibit agrifood exports. A guide for policy analysts and planners. In Food and Agriculture Organization; Agricultural Services Bulletin 60; FAO: Rome, Italy, 2005.

4. Neven, D. Developing Sustainable Food Value Chains. In Guiding Principles; Food and Agriculture Organization of the United Nations (FAO): Rome, Italy, 2014; pp. 86-89.

5. Malabo Montpellier Panel. Mechanized: Transforming Africa's Agriculture Value Chains. 2018. Available online: www.mamopanel.org/media/uploads/files/MaMo_2018_Mechanisiert_web.pdf (accessed on 20 August 2019).

6. High Level Panel of Experts on Food Security and Nutrition of the Committee on World Food Security (HLPE). Food Losses and Waste in the Context of Sustainable Food Systems. Rome, Italy. 2014. Available online: http://www.fao.org/3/a-i3901e.pdf (accessed on 20 August 2019).

7. Manda, J.; Alene, A.D.; Gardebroek, C.; Kassie, M.; Tembo, G. Adoption and Impacts of Sustainable Agricultural Practices on Maize Yields and Incomes: Evidence from Rural Zambia. J. Agric. Econ. 2016, 67, 130-153. [CrossRef]

8. Mnimbo, T.S.; Lyimo-Macha, J.; Urassa, J.K.; Mahoo, H.F.; Tumbo, S.D.; Graef, F. Influence of gender on roles, choices of crop types and value chain upgrading strategies in semi-arid and sub-humid Tanzania. Food Secur. 2017, 9, 1173-1187. [CrossRef] 
9. Kassie, M.; Teklewold, H.; Jaleta, M.; Marenya, P.; Erenstein, O. Understanding the adoption of a portfolio of sustainable intensification practices in eastern and southern Africa. Land Use Policy 2015, 42, 400-411. [CrossRef]

10. Graef, F.; Uckert, G.; Schindler, J.; König, H.J.; Mbwana, H.A.; Fasse, A.; Mwinuka, L.; Mahoo, H.; Kaburire, L.N.; Saidia, P.; et al. Expert-based ex-ante assessments of potential social, ecological, and economic impacts of upgrading strategies for improving food security in rural Tanzania using the ScalA-FS approach. Food Secur. 2016, 9, 1255-1270. [CrossRef]

11. Graef, F.; Sieber, S.; Mutabazi, K.; Asch, F.; Biesalski, H.K.; Bitegekof, J.; Bokelmann, W.; Bruentrup, M.; Dietrich, O.; Elly, N.; et al. Framework for participatory food security research in rural food value chains. Glob. Food Secur. 2014, 3, 8-15. [CrossRef]

12. Adeyele, O.; Bako, S.; Afiemo, O.G.; Alli-Balogun, K.; Agbo, R. Role of local innovation in mechanisation of maize shelling: Evidence from Igabi, Chikun and Kajuru Local Government Areas, Kaduna State Nigeria. J. Agric. Ext. Rural Dev. 2015, 7, 170-175. [CrossRef]

13. Trans-SEC. 2014. Available online: http://project2.zalf.de/trans-sec/public/ (accessed on 15 October 2017).

14. Schindler, J.; Graef, F.; König, H.J.; Mchau, D. Developing community based food security criteria in rural Tanzania. Food Secur. 2017, 9, 1285-1298. [CrossRef]

15. Riisgaard, L.; Bolwig, S.; Matose, F.; Ponte, S.; du Toit, A.; Halberg, N. A Strategic Framework and Toolbox for Action Research with Small Producers in Value Chains. Copenhagen: DIIS. Working Paper. 2008. Available online: https://www.econstor.eu/bitstream/10419/44681/1/573597898.pdf (accessed on 20 March 2018).

16. Rogers, E.M. Diffusion of Innovations, 5th ed.; Free Press: New York, NY, USA, 2003.

17. Adesina, A.A.; Zinnah, M.M. Technology characteristics, farmers' perceptions and adoption decisions: A Tobit model analysis in Sierra Leone. Agric. Econ. 1993, 9, 297-311. [CrossRef]

18. Feder, G.R.; Just, R.E.; Zilberman, D. Adoption of agricultural innovations in developing countries: A survey. Econ. Dev. Cult. Chang. 1985, 33, 255-298. [CrossRef]

19. Ghadim, A.K.A.; Pannell, D.J. A conceptual framework of adoption of an agricultural innovation. Agric. Econ. 1999, 21, 145-154. [CrossRef]

20. Sunding, D.; Zilberman, D. The Agricultural Innovation Process: Research and Technology Adoption in a Changing Agricultural Sector. In Handbook of Agricultural Economics, Volume 1 A Agricultural Production; Gardner, B.L., Rausser, G.C., Eds.; Elsevier: New York, NY, USA, 2001; Available online: https://www. sciencedirect.com/science/article/pii/S1574007201100071 (accessed on 20 March 2018).

21. Isham, J. The effect of social capital on fertilizer use. J. Afr. Econ. 2002, 11, 39-60. [CrossRef]

22. Barrett, C.B. Smallholder market participation: Concepts and evidence from eastern and southern Africa. Food Policy 2008, 33, 299-317. [CrossRef]

23. Amare, M.; Asfaw, S.; Shiferaw, B. Welfare impacts of maize-pigeonpea intensification in Tanzania. Agric. Econ. 2012, 43, 1-17. [CrossRef]

24. Seymour, G.; Doss, C.R.; Paswel, M.; Ruth, S.M.D.; Passarelli, S. Women's empowerment and the adoption of improved maize varieties: Evidence from Ethiopia, Kenya and Tanzania. In Proceedings of the Agricultural \& Applied Economics Association's Annual Meeting, Boston, MA, USA, 31 July-2 August 2016; Available online: https://cgspace.cgiar.org/handle/10568/76523 (accessed on 20 March 2018).

25. Doss, C.R. Analyzing technology adoption using microstudies: Limitations, challenges, and opportunities for improvement. Agric. Econ. 2006, 34, 207-219. [CrossRef]

26. Uaiene, R.N.; Arndt, C.; Masters, W.A. “Determinants of Agricultural Technology Adoption in Mozambique." International Food policy Research Institute, Mozambique. 2009. Available online: https:/tropicalsoybean.com/sites/default/files/Determinants\%20of\%20Agricultural\%20Technology\% 20Adoption\%20in\%20Mozambique_Uaiene.pdf (accessed on 30 May 2020).

27. Pender, J.; Gebremedhin, B. Determinants of agricultural and land management practices and impacts on crop production and household income in the highlands of Tigray, Ethiopia. J. Afr. Econ. 2007, 17, 395-450. [CrossRef]

28. Morris, S.S.; Carletto, C.; Hoddinott, J.; Christiaensen, L.J.M. Validity of rapid estimates of household wealth and income for health surveys in rural Africa. J. Epidemiol. Community Health 2000, 54, 381-387. [CrossRef]

29. Reardon, T.; Stamoulis, K.; Pingali, P. Rural Nonfarm Employment in Developing Countries in an era of Globalization. Agric. Econ. 2007, 37, 173-183. [CrossRef] 
30. Ellis, F.; Freeman, H.A. Rural Livelihoods and Poverty Reduction Strategies in Four African Countries. J. Dev. Stud. 2004, 40, 1-30. [CrossRef]

31. Goodwin, B.K.; Mishra, A.K. Farming efficiency and the determinants of multiple job holding by farm operators. Am. J. Agric. Econ. 2004, 86, 722-729. [CrossRef]

32. Lee, D.R. Agricultural Sustainability and Technology Adoption: Issues and Policies for Developing Countries. Am. J. Agric. Econ. 2005, 87, 1325-1334. [CrossRef]

33. Kassie, M.; Jaleta, M.; Shiferaw, B.; Mmbando, F.; Mekuria, M. Adoption of interrelated sustainable agricultural practices in smallholder systems: Evidence from rural Tanzania. Technol. Forecast. Soc. Chang. 2013, 80, 525-540. [CrossRef]

34. Idrisa, Y.L.; Ogunbameru, B.O.; Madukwe, M.C. Logit and Tobit analyses of the determinants of likelihood of adoption and extent of adoption of improved soybean seed in Borno State, Nigeria. Greener J. Agric. Sci. 2012, 2, 37-45. [CrossRef]

35. Gebremedehin, B.; Scott, M.S. Investment in soil conservation in northern Ethiopia: The role of land tenure security and public programs. Agric. Econ. 2003, 29, 69-84. [CrossRef]

36. Teklewold, H.; Köhlin, G. Risk preferences as determinants of soil conservation decisions in Ethiopia. 2010. Available online: https://www.researchgate.net/publication/46456062_Risk_Preferences_as_Determinants_ of_Soil_Conservation_Decisions_in_Ethiopia (accessed on 20 March 2018).

37. Cavatassi, R.; Lipper, L.; Narloch, U. Modern variety adoption and risk management in drought prone areas: Insights from the sorghum farmers of eastern Ethiopia. Agric. Econ. 2011, 42, 279-292. [CrossRef]

38. Grothmann, T.; Patt, A. Adaptive capacity and human cognition: The process of individual adaptation to climate change. Glob. Environ. Chang. 2005, 15, 199-213. [CrossRef]

39. Guidi, D. Sustainable Agriculture Enterprise: Farming Strategies to Support Smallholder Inclusive Value Chains for Rural Poverty Alleviation. CID Research Fellow and Graduate Student Working Paper No. 53. Center for International Development at Harvard University. 2011. Available online: https://ideas.repec.org/ p/cid/wpfacu/53.html (accessed on 20 March 2018).

40. Asfaw, S.; Shiferaw, B.; Simtowe, F.; Lipper, L. Impact of modern agricultural technologies on smallholder welfare: Evidence from Tanzania and Ethiopia. Food Policy 2012, 37, 283-295. [CrossRef]

41. Shiferaw, B.A.; Kebede, T.A.; You, L. Technology adoption under seed access constraints and the economic impacts of improved pigeonpea varieties in Tanzania. Agric. Econ. 2008, 39, 309-323. [CrossRef]

42. United Nations Development Programme (UNDP). Human Development Indices and Indicators 2018. 2019. Available online: http://hdr.undp.org/sites/all/themes/hdr_theme/country-notes/TZA.pdf (accessed on 3 February 2020).

43. Rowhani, P.; Lobell, D.B.; Linderman, M.; Ramankutty, N. Climate variability and crop production in Tanzania. Agric. Forest Meteorol. 2011, 151, 449-460. [CrossRef]

44. United Republic of Tanzania (URT). National Sample Census of Agriculture 2007/2008: Regional Report: Morogoro Region. Dar es Salaam: URT. 2012. Available online: https://www.ocgs.go.tz/php/ReportOCGS/ Zanzibar\%20Agriculture\%20Sample\%20Census\%20Livestock\%20Report\%20Final\%202009.pdf (accessed on 20 March 2018).

45. National Bureau of Statistics (NBS). Basic Facts and Figures on Human Settlements 2012. Tanzania Mainland. Dar es Salaam: Ministry of Finance. 2014. Available online: https://www.nbs.go.tz/index.php/en/census-surveys/environmental-statistics/75-basic-facts-and-figureson-human-settlements-2012-tanzania-mainland (accessed on 22 March 2018).

46. Kiunsi, R.B. A Review of Traffic Congestion in Dar es Salaam City from the Physical Planning Perspective. J. Sustain. Dev. 2013, 6, 94-103. [CrossRef]

47. Minot, N.; Simler, K.; Benson, T.; Kilama, B.; Luvanda, E.; Makbel, A. Poverty and Malnutrition in Tanzania: New Approaches for Examining Trends and Spatial Patterns. Washington D.C.: International Food Policy Research Institute. 2006. Available online: http://www.repoa.or.tz/documents_storage/Research\%20and\% 20Analysis/IFPRI\%20Report.pdf (accessed on 21 March 2018).

48. Mnenwa, R.; Maliti, E. A comparative analysis of poverty incidence in farming systems of Tanzania. Special Paper 10/4, Research on Poverty Alleviation (REPOA), Dar es Salaam. 2010. Available online: http://www.repoa.or.tz/documents/10-4_web-1.pdf (accessed on 20 March 2018).

49. Schneider, U.; Wagner, M. Catching Growth Determinants with the adaptive lasso. German Econ. Rev. 2012, 13, 71-85. [CrossRef] 
50. Ali, D.A.; Derick, B.; Deininger, K. Personality Traits, Technology Adoption, and Technical Efficiency: Evidence from Smallholder Rice Farms in Ghana. World Bank Policy Research Working Paper No. 7959. 2017. Available online: https://ssrn.com/abstract=2910738 (accessed on 15 November 2017).

51. Zou, H. The Adaptive Lasso and Its Oracle Properties. J. Am. Stat. Assoc. 2006, 101, 1418-1429. [CrossRef]

52. Tibshirani, R. Regression Shrinkage and Selection via the Lasso. J. Royal Stat. Soc. 1996, 58, 267-288. [CrossRef]

53. Hosmer, D.W.; Lemeshow, S. Applied Logistic Regression; Wiley: New York, NY, USA, 1989.

54. Chan, Y.H. Multinomial logistic regression. Biostatistics 305. Singap. Med. J. 2005, 46, 259-269.

55. Wooldridge, J.M. Econometric Analysis of Cross Section and Panel Data, 2nd ed.; Massachusetts Institute of Technology, MIT Press: Cambridge, MA, USA, 2010; pp. 561-585.

56. Wijnand, H.; Van De Velde, R. Mann-Whitney/Wilcoxon's nonparametric cumulative probability distribution. Comput. Methods Programs Biomed. 2000, 63, 21-28. [CrossRef]

57. Caliendo, M.; Kopeinig, S. Some practical guidance for the implementation of propensity score matching. J. Econ. Surv. 2008, 22, 31-72. [CrossRef]

58. Rosenbaum, P.R.; Rubin, R. The central role of the propensity score in observational studies for causal effects. Biometrika 1983, 70, 41-55. [CrossRef]

59. Teklewold, H.; Kassie, M.; Shiferaw, B.; Köhlin, G. Cropping system diversification, conservation tillage and modern seed adoption in Ethiopia: Impacts on household income, agrochemical use and demand for labor. Ecol. Econ. 2013, 93, 85-95. [CrossRef]

60. Bryson, A.; Dorsett, R.; Purdon, S. The Use of Propensity Score Matching in the Evaluation of Labour Market Policies. Working Paper 4, London: Department for Work and Pensions. 2002. Available online: http://eprints.lse.ac.uk/4993/ (accessed on 20 March 2018).

61. Becker, S.O.; Ichino, A. Estimation of Average Treatment Effects Based on Propensity Scores. Stata J. 2002, 2, 358-377. [CrossRef]

62. Heckman, J.; Ichimura, H.; Todd, P.E. Matching as an econometric evaluation estimator: Evidence from evaluating a job training programme. Rev. Econ. Stud. 1997, 64, 605-654. [CrossRef]

63. Dehejia, R.H.; Wahba, S. Propensity Score Matching Methods for Non-Experimental Causal Studies. Rev. Econ. Stat. 2002, 84, 151-161. [CrossRef]

64. Rosenbaum, P.R. Covariance Adjustment in Randomized Experiments and Observational Studies. Stat. Sci. 2002, 17, 286-327.

65. Kassie, M.; Shiferaw, B.; Muricho, G. Agricultural technology, crop income, and poverty alleviation in Uganda. World Dev. 2011, 39, 1784-1795. [CrossRef]

66. Bokusheva, R.; Finger, R.; Fischler, M.; Berlin, R.; Marín, Y.; Pérez, F.; Paiz, F. Factors determining the adoption and impact of a postharvest storage technology. Food Secur. 2012, 4, 279-293. [CrossRef]

67. Tefera, T.; Abass, A.B. Improved Postharvest Technologies for Promoting Food Storage, Processing, and Household Nutrition in Tanzania. International Institute of Tropical Agriculture. 2012. Available online: https://cgspace.cgiar.org/bitstream/handle/10568/24886/aresa_postharvest.pdf?sequence=1 (accessed on 20 March 2018).

68. Carletto, C.; Corral, P.; Guelfi, A. Agricultural commercialization and nutrition revisited: Empirical evidence from three African countries. Food Policy 2017, 67, 106-118. [CrossRef]

69. Afolami, C.; Obayelu, A.; Vaughan, I. Welfare impact of adoption of improved cassava varieties by rural households in South Western Nigeria. Agric. Food Econ. 2015, 3, 1-17. [CrossRef]

70. Abdulai, A.; Huffman, W.E. The Diffusion of New Agricultural Technologies: The Case of Crossbred-Cow Technology in Tanzania. Am. J. Agric. Econ. 2005, 87, 645-659. [CrossRef]

71. De Groote, H.; Hall, M.D.; Spielman, D.J.; Mugo, S.; Andam, K.; Munyua, B.G. Options for pro-poor maize seed market segmentation in Kenya. Afr. J. Biotechnol. 2011, 10, 4699-4712.

72. Doss, C.R.; Morris, M. How does gender affect the adoption of agricultural innovations? The case of improved maize technology in Ghana. Agric. Econ. 2001, 25, 27-39. [CrossRef]

73. Mwangi, M.; Kariuki, S. Factors determining adoption of new agricultural technology by smallholder farmers in developing countries. J. Econ. Sustain. Dev. 2015, 6, 208-216.

(C) 2020 by the authors. Licensee MDPI, Basel, Switzerland. This article is an open access article distributed under the terms and conditions of the Creative Commons Attribution (CC BY) license (http://creativecommons.org/licenses/by/4.0/). 